\title{
Zinc, a Neurotoxin to Cultured Neurons, Contaminates Cycad Flour Prepared by Traditional Guamanian Methods
}

\author{
Mark W. Duncan, ${ }^{1}$ Ann M. Marini, ${ }^{1}$ Robert Watters, ${ }^{2}$ Irwin J. Kopin, ${ }^{1}$ and Sanford P. Markey ${ }^{3}$ \\ 'Intramural Research Program, National Institute of Neurological Disorders and Stroke, National Institutes of Health, \\ Bethesda, Maryland 20892, 2National Institutes of Standards and Technology, Gaithersburg, Maryland 20899, and \\ ${ }^{3}$ Section on Analytical Biochemistry, National Institute of Mental Health, National Institutes of Health, Bethesda, \\ Maryland 20892
}

\begin{abstract}
We have used cultured ventral mesencephalic and cerebellar granule cells to test the toxicity of extracts of cycad seeds (genus Cycas) and cycad-derived flours traditionally prepared in Guam. There was no significant difference in the toxicity of extracts prepared from the female gametophyte tissue of $C$. circinalis, $C$. revoluta, and $C$. media, common wheat flour, and 13 of 17 cycad flour samples. However, extracts prepared from 4 of 17 Guamanian flour samples exhibited marked dose-dependent neurotoxicity to mesencephalic and granule cell cultures. There was no correlation between toxicity and 2-amino-3-(methylamino)-propanoic acid (BMAA) content, and the concentration of BMAA in the medium arising from these extracts was far below that required to be neurotoxic. Toxicity of extracts was not blocked by the NMDA receptor antagonist MK-801 or the non-NMDA receptor antagonist 6-cyano-7-dinitroquinoxaline-2,3-dione, indicating that toxicity was not mediated by excitatory amino acid receptors. Analysis of the four toxic processed flour samples indicated high zinc content. Zinc produced a concentration-dependent neurotoxic response in mesencephalic and granule cell cultures that paralleled the calculated concentrations of zinc in the cultures derived from the four toxic flour samples. When sliced $C$. circinalis gametophyte tissue was "processed" in our laboratory by soaking in a galvanized container, there was a time-dependent increase in zinc content.
\end{abstract}

Environmental factors are considered to be responsible for the high incidence of amyotrophic lateral sclerosis parkinsonism dementia (ALS-PD) in the western Pacific region, but the causative agent is unknown (Garruto and Yase, 1974; Spencer et al., 1987a; Kurland, 1988). Since the early 1960s, cycads, particularly

\footnotetext{
Received May 13, 1991; revised Oct. 14, 1991; accepted Nov. 26, 1991.

We thank Drs. J. Steele and L. Lavine for providing the flour samples included in this study, and Dr. M. Palmatier for the preparation of ventral mesencephalic cultures. Drs. R. Garruto and M. Strong (NINDS) critically evaluated our data and discussed many aspects of this work with us. Studics on the incorporation of zinc into cycad seed gametophyte tissue were undertaken in our laboratory by Philip Pearson. We also thank Drs. Q. Smith (NIA), R. Cohen (NIMH), H. Fales (NHLBI), J. Schwartz and M. Brightman (NINDS), F. Abramson (George Washington University), L. Kurland (Mayo Clinic), and D. Choi (Stanford University) for fruitful discussions. Leila Brosnan assisted us during the preparation of the manuscript.

Correspondence should be addressed to Dr. Mark W. Duncan, Biomedical Mass Spectrometry Unit, Wallace Wurth Medical Building, University of New South Wales, P.O. Box 1, Kensington, N.S.W. 2033, Australia.

Copyright (C) 1992 Society for Neuroscience $0270-6474 / 92 / 121523-15 \$ 05.00 / 0$
}

members of the genus Cycas, have been implicated in the pathogenesis of this disorder in this region (Whiting, 1963). Data in support of this association come from the demonstration that the cycad component 2-amino-3-(methylamino)-propanoic acid (or $\beta$-methylamino-L-alanine; BMAA) is neurotoxic when administered to primates at high doses for prolonged intervals (i.e., greater than $100 \mathrm{mg} / \mathrm{kg}$ for approximately 12 weeks) (Spencer et al., 1987). BMAA has also been shown to be neurotoxic to cultured mouse motor neuronal explants, and toxicity appears to be mediated by the NMDA receptor (Nunn et al., 1987; Ross et al., 1987). However, we have argued that there is insufficient evidence to link BMAA causally to neurological disorders. A diet high in cycad flour prepared by the traditional washing procedure provides low levels of BMAA (Duncan et al., 1988, 1990), and medicinal use of cycads is unlikely to provide neurotoxic quantities of this compound (Duncan, 1991).

In view of the renewed interest in cycads as an etiologic agent, we sought to examine the hypothesis that an unidentified cycad constituent is the neurotoxic agent. The most compelling evidence to suggest that there is a link between cycads and ALS$\mathrm{PD}$ is epidemiological and does not implicate any specific component. For example, support for a link between cycads and ALS-PD comes from the finding that food or medicinal use of members of the genus Cycas is common to all three high incidence foci for this disorder: Guam, west New Guinea, and the Kii peninsula of Japan (Spencer et al., 1986, 1987a-c). Therefore, we have investigated the neurotoxicity of cycads by a combination of chemical techniques (i.e., extraction, isolation, and structural elucidation) and neurotoxicity testing using cultured neurons. We now report on studies of the toxicity of a collection of cycad seed samples and cycad-derived flours.

\section{Materials and Methods}

\section{Sample collection and selection}

Processed $C$. circinalis flour samples were prepared by Chamorro indigenes of Guam. The precise method of preparation varies, but traditionally processing involves sectioning of the ripe seeds followed by removal of the gametophyte tissue, and a series of water washes to remove acutely toxic water-soluble constituents. These sections are then sun dried and stored. Before use, the dried cycad chips are ground into a fine flour. (We have discussed the traditional method of preparation in more detail in Duncan et al., 1990.)

Of the 21 flour samples available to us, 6 were initially tested for neurotoxicity in cell culture. One of these samples was markedly toxic and was found to contain high levels of zinc. Subsequent analysis of all 21 flour samples found an elevated zinc content in 4 . Thereafter, 17 
randomly selected samples (including the 4 toxic samples) were employed in our studies.

\section{Preparation of cycad flour in the laboratory}

Unprocessed cycad flour samples were prepared by drying sliced female gametophyte tissue $\left(40^{\circ} \mathrm{C}\right)$ to constant weight. We prepared our own samples of processed $C$. circinalis flour by replicating the traditional method in the laboratory. Female gametophyte tissue of fresh seeds was sectioned and soaked in distilled water in a galvanized iron bucket. Each day, the wash water was changed, and a sample of the seed tissue was removed, dried, and ground into flour. Soaking continued for $7 \mathrm{~d}$.

\section{Extract preparation}

All extractions were carried out in glass screw-capped tubes $(7 \mathrm{ml} \mathrm{ca-}$ pacity). Extracts of the finely ground sample $(0.5-1.0 \mathrm{gm})$ flour were prepared by vigorously shaking with dilute hydrochloric acid $(5 \mathrm{ml}, 0.1$ M) for periods of up to $30 \mathrm{hr}$. Ultrasonic disruption was employed midway through the extraction period to maximize recoveries. After extraction, samples were centrifuged for $15 \mathrm{~min}$ until a clear supernatant was obtained $\left(980 \times g, 10^{\circ} \mathrm{C}\right)$, and a portion $(1 \mathrm{ml})$ was filtered (Millipore membrane filter), transferred to preweighed glass tubes, and dried under vacuum (Speedvac, Savant Inc., Hicksville, NY). An aliquot of each flour extract $(\approx 1 \mathrm{ml})$ was stored at $-20^{\circ} \mathrm{C}$ until gas chromatographicmass spectrometric (GC/MS) determination of BMAA content. Assays were performed within 1 week of sample preparation.

\section{Quantification of BMAA in Cycas circinalis flour extracts}

Total (i.e., free + conjugated) BMAA levels in samples were determined by GC/MS according to the procedure we have described previously (Duncan et al., 1989, 1990). This assay involves addition of a stable deuterated isotopomer standard followed by conversion of BMAA to the isobutyl ester and subsequent pentafluoracylation to yield a volatile derivative. Samples were analyzed in the selected ion monitoring mode and the BMAA content was calculated from the ion abundance ratios for BMAA and the deuterated isotopomer standard by reference to a standard curve.

\section{Metal ion analysis}

Direct current (DC) arc analysis of flour extracts. The extracts (prepared as described above) were evaporated in carbon cup electrodes and their arc spectra recorded on photographic plates. Sample spectra were compared to standard spectral plates for identification and quantification of the analyte elements. This approach was used for a semiquantitative survey analysis of over 50 inorganic elements in the cycad extracts.

Inductively coupled plasma analysis of flour extracts. For more precise and accurate quantification, selected extracts were analyzed for aluminum, manganese, zinc, arsenic, cadmium, lead, and selenium by inductively coupled plasma (ICP) spectrometry. The extracts were aspirated directly into the ICP, which was calibrated using pure element standards.

Inductively coupled plasma analysis of zinc in flour samples. Subsequently, all processed flours were analyzed for zinc by completely dissolving the solid flours and introducing the sample solutions into the ICP. Approximately $0.25 \mathrm{gm}$ of each sample was weighed into Teflon beakers. Distilled water $(10 \mathrm{ml})$, nitric acid $(5 \mathrm{ml})$, and hydrofluoric acid $(2 \mathrm{ml})$ were added to each. The beakers were covered and heated on a hot plate for about $2 \mathrm{hr}$. The covers were removed and perchloric acid $(10 \mathrm{ml})$ was added to each beaker. The samples were then heated to complete evolution of perchloric acid fumes to digest all the organic matter. The solutions were evaporated to about $1-2 \mathrm{ml}$ and were transferred to $50 \mathrm{ml}$ volumetric flasks. Each flask was diluted to volume with distilled water. This method has been verified to be quantitative for National Institute of Standards and Technology Standard Reference Material 1568, Wheat Flour.

\section{Cell culture preparation and toxicity testing}

\section{Preparation of cerebellar granule cells}

Cultured rat cerebellar granule cells were prepared as described previously (Gallo et al., 1987; Marini et al., 1989). The cells were maintained at $37^{\circ} \mathrm{C}$ in a humidified atmosphere of $95 \%$ air, $5 \% \mathrm{CO}_{2}$. The culture medium was always maintained at $2 \mathrm{ml}$ by replacing evaporative losses with sterile water. Beginning on day in vitro (DIV) 7 , and every third day thereafter, D-glucose $(100 \mathrm{~mm}, 100 \mu \mathrm{l})$ was added to the culture medium. Under these conditions, cerebellar granule cells survive for up to $40 \mathrm{~d}$ in culture. Cerebellar astrocytes were $5 \%$ of the total population as indicated by glial fibrillary acidic protein (GFAP) immunofluorescence (Marini et al., 1989).

\section{Preparation of ventral mesencephalic neurons}

The rat ventral mesencephalic neurons we employed were prepared as detailed elsewhere (Di Porzio et al., 1980), with some modifications. Briefly, ventral mesencephalons from 14-d-old rat embryos were placed in a phosphate-buffered saline solution containing glucose ( $33 \mathrm{~mm})$. The tissue was triturated twice in serum-containing media [ $50 \mathrm{ml}$ of minimal essential media $/ 50 \mathrm{ml}$ of Ham's F-10; $7.5 \%$ horse serum; 2 mm glutamine; $3 \mathrm{mM} \mathrm{Na}_{2} \mathrm{CO}_{3} ; 33 \mathrm{~mm}$ D-glucose; $1 \mathrm{ml}$ of penicillin/streptomycin/ neomycin $(5000 \mathrm{U}$ of penicillin, $5 \mathrm{mg}$ of streptomycin, and $10 \mathrm{mg}$ of neomycin sulfate per $\mathrm{ml}$ ) per $100 \mathrm{ml}$ of media]. The cells were then seeded at $1.5 \times 10^{5}$ cells $/ \mathrm{cm}^{2}$ in 24 well plates (final volume, $0.5 \mathrm{ml}$ ) previously coated with $1.5 \mu \mathrm{g} / \mathrm{cm}^{2} \mathrm{~L}$-polyornithine. The cultures were maintained in a humidified atmosphere of $95 \%$ air, $5 \% \mathrm{CO}_{2}$ and incubated at $37^{\circ} \mathrm{C}$. Astrocytes in the ventral mesencephalic cultures were identified by immunoreactivity for GFAP (Lipsky and Silverman, 1987). Tyrosine hydroxylase immunocytochemistry was performed to ensure that the proper brain region (ventral mesencephalon) was removed and cultured.

\section{Tyrosine hydroxylase immunocytochemistry}

The cultures were washed in phosphate-buffered saline (PBS), fixed with formaldehyde (37\%):glacial acetic acid:ethanol (80\%) (2:1:18) for $20 \mathrm{~min}$ at room temperature, and rinsed three times with PBS over a $20 \mathrm{~min}$ interval. They were incubated in blocking solution [ $10 \%$ goat serum in carrier solution ( $1 \%$ goat serum, $1 \%$ BSA, $0.3 \%$ Triton X-100 in PBS)] for $2 \mathrm{hr}$ at room temperature and then incubated overnight at $4^{\circ} \mathrm{C}$ with a rabbit anti-tyrosine hydroxylase (anti- $\mathrm{TH}$ ) antibody (Vector Laboratories, Burlingame, $\mathrm{CA}$ ) diluted $1: 300$ in carrier solution. The cultures were washed in carrier solution for $30 \mathrm{~min}$ at room temperature; incubated with biotinylated anti-rabbit IgG diluted 1:200 in $50 \mathrm{~mm}$ Tris$\mathrm{HCl}, 0.85 \% \mathrm{NaCl} \mathrm{pH} 7.6$ (buffer $\mathrm{A}$ ) for $60 \mathrm{~min}$; and washed again in carrier solution for $30 \mathrm{~min}$. The cultures were incubated for $30 \mathrm{~min}$ with a preformed avidin-biotinylated horseradish peroxidase in buffer $A$ and rinsed in carrier solution as described above. The peroxidase was revealed by incubating the cultures with a solution consisting of a Tris$\mathrm{HCl}$ buffer $\mathrm{pH} 7.2(20 \mathrm{ml})$ containing $8 \% \mathrm{NiCl}_{2}(100 \mu \mathrm{l}), \mathrm{H}_{2} \mathrm{O}_{2}(13.5$ $\mu 1)$, and diaminobenzidine $(10 \mathrm{mg})$. After $30 \mathrm{~min}$ at room temperature, the reaction was stopped by removing the solution and adding tap water.

\section{Neurotoxicity testing}

The dry cycad or flour extracts were reconstituted in culture medium ( $1 \mathrm{ml}$, cerebellar granule cells; $2 \mathrm{ml}$, ventral mesencephalic cultures) and adjusted to $\mathrm{pH} 7$ with sodium hydroxide $(0.2 \mathrm{M}, 10-12 \mu \mathrm{l})$. The extracts were centrifuged $(890 \times \mathrm{g})$ at room temperature for 15 minutes, and the supernatant was removed, filter sterilized, and added to the culture dishes or wells. Variable amounts of extract (10-100 $\mu$, cerebellar granule cells; $5-40 \mu$, ventral mesencephalic cells) were added to the culture medium, and the cells were examined thereafter. All samples were tested in duplicate, and studies were repeated using at least four different batches of cultures. Zinc chloride and EDTA were prepared in deionized water, and the EDTA solution was adjusted to $\mathrm{pH} 7$ with sodium hydroxide and added to the cultures in culture medium on the DIV indicated. For the zinc chloride and EDTA experiments, sister cultures were treated with the identical volume of water. Sample blanks, solvent blanks, and household wheat flour were used as controls throughout the studies. All flour extracts or test samples were added to ventral mesencephalic cultures on DIV 6. Twenty-four hours later, the cells were fixed and stained for tyrosine hydroxylase by immunocytochemistry as described above. Extracts were added to cerebellar granule cell cultures on DIV 4,5 , or 10 .

\section{Assessment of neuronal viability in cerebellar granule cell and ventral mesencephalic cultures}

Cerebellar granule cell viability was quantified with fluorescein diacetate [a stock solution of $5 \mathrm{mg} / \mathrm{ml}$ was prepared in acetone and diluted $1 / 1000$ in modified Locke's solution (154 mM NaCl, $5.6 \mathrm{~mm}$ glucose, 
8.6 mм HEPES, $5.6 \mathrm{~mm} \mathrm{KCl}, 2.3 \mathrm{~mm} \mathrm{CaCl}, 1.0 \mathrm{~mm} \mathrm{MgCl}_{2}$, pH 7.4) to a final concentration of $5 \mu \mathrm{g} / \mathrm{ml}$ ] by incubating the culture dishes at $37^{\circ} \mathrm{C}$ for $5 \mathrm{~min}$, removing the fluorescein diacetate solution, replacing it with fresh modified Locke's solution, and examining the cells immediately by fluorescence microscopy (Novelli et al., 1988). Viability is expressed as the percentage of the number of fluorescein-positive cells in treated cultures in randomly selected microscopic fields compared to control untreated cultures. The number of fluorescein diacetate-positive neurons correlated exactly with the number of neurons phasecontrast bright and refractive to light (Novelli et al., 1988). In some experiments, the percentage of neurons phase-contrast bright and refractive to light in treated compared to control neurons was used to assess neuronal viability. Viable neurons in each culture were counted by an investigator who was "blind" to the sample origin. In ventral mesencephalic neuronal cell cultures, the percentage of refractile neurons in treated compared to control cultures was used to assess neuronal viability.

\section{Sample hydrolysis for neurotoxicity testing on cerebellar granule cells}

Flour samples were extracted as described above and centrifuged, and an aliquot $(1 \mathrm{ml})$ of the supernatant was removed and dried under vacuum. The dried residue was dissolved in $\mathrm{HCl}(6 \mathrm{M}, 1 \mathrm{ml})$ for $18 \mathrm{hr}$ at $110^{\circ} \mathrm{C}$ under an atmosphere of nitrogen. After hydrolysis, the sample was again dried under vacuum and the residue reconstituted in tissue culture medium $(1 \mathrm{ml})$. The $\mathrm{pH}$ of the sample was adjusted to 7 , the sample was centrifuged, and the supernatant was removed and added to cerebellar granule cell cultures as described above. A portion $(20 \mu \mathrm{l})$ of the hydrolyzed sample was removed prior to drying, deuterated internal standard was added, and the BMAA content was determined as described below.

\section{Removal of the toxicity of the most toxic cycad flour extracts}

Ammonium sulfide ( 5 drops) was added to the two most toxic cycad flour extracts ( $2 \mathrm{ml}$ of the solution obtained from $1 \mathrm{gm}$ of flour extracted with $10 \mathrm{ml}$ of $0.1 \mathrm{M} \mathrm{HCl}$ ) to precipitate metals as their insoluble sulfides. After mixing, the solution was allowed to stand for $30 \mathrm{~min}$ and centrifuged, and the clear supernatant was removed and taken to dryness under vacuum. A control sample prepared from household flour was treated in an identical manner. The dried residues were then reconstituted in culture medium and tested for toxicity on cerebellar granule cells as described above.

\section{Reagents}

Reagents (analytical grade) and solvents (HPLC grade) were obtained from commercial suppliers and used without further purification. Ammonium sulfide (20\% in water) was obtained from Aldrich Chemical Co. Racemic ${ }^{2} \mathrm{H}_{3}-\mathrm{BMAA} \cdot \mathrm{HCl}$ was prepared according to previously described methods (Duncan et al., 1989); BMAA. $\mathrm{HCl}$ was obtained from RBI. Fluorescein diacetate, EDTA, trypsin, soybean trypsin inhibitor, and deoxyribonuclease I were purchased from Sigma Chemicals. Basal Medium Eagle, glutamine, and fetal calf serum were obtained from Grand Island Biological Company. (+)MK-801 and L-BMAA $\cdot \mathrm{HCl}$ were purchased from Research Biochemicals. Throughout this article, we use the abbreviation BMAA to refer to the naturally occurring L-isomer.

\section{Animals}

Eight-day-old Sprague-Dawley rat pups (15-19 gm) were obtained from Taconic Farms (Germantown, NY).

\section{Results}

\section{Neurotoxicity testing of cycad extracts in cerebellar granule} cells

Initially, we employed cerebellar granule cells for neurotoxicity testing because an excitatory amino acid, such as BMAA, had been implicated as the toxic constituent (Spencer et al., 1987a). Therefore, extracts derived from the gametophyte tissue of $C$. circinalis, C. revoluta, and C. media, 17 flour samples prepared in the traditional manner by Guamanians, and household wheat flour were tested for toxicity in this culture system. In the first series of studies, the extracts added to the cultures contained all the acid-soluble components derived from $5 \mathrm{mg}$ of each sample. Three Guamanian prepared flour extracts exerted a marked neurotoxic response, and a fourth extract was somewhat less toxic, whereas extracts prepared from the gametophyte tissue of the three seed types, household wheat flour, and extracts from 13 flour samples elicited no neurotoxic response.

Figure $1 a$ illustrates a typical granule cell culture (DIV 10). Viable neuronal cell bodies are phase bright and refractive to light; extensive neurite networking and the number of granule cell neurons are prominent features of this culture (about $95 \%$ of the population are granule cells). When cultures of cerebellar granule cells were exposed to extracts prepared from $5 \mathrm{mg}$ of the most toxic flour samples, neuronal swelling, loss of refractility, and neurite disruption were observed within $6 \mathrm{hr}$ (Fig. 1b). No toxicity was found in cultures treated with extracts of an equivalent amount of commercial wheat flour (see Fig. 1c). When extracts were added to cerebellar granule cell neurons at earlier culture times (i.e., <DIV 8), the onset of neuronal disintegration was delayed (i.e., $\sim 24 \mathrm{hr}$ ).

Vital staining with fluorescein diacetate was used to examine viability of cerebellar granule cells. A dense neuronal cell population and extensive neurite networking are prominent features of cultured cerebellar granule cells (Fig. $2 a$ ). However, exposure of the cells to extracts derived from the equivalent of $5 \mathrm{mg}$ of the neurotoxic flour results in almost complete granule cell destruction and disappearance of their neurites (Fig. $2 b$ ). The brilliant fluorescence of the cerebellar astrocytes in the culture indicates that these cells were not affected by the toxic flour extract. The number of fiuorescent neurons, and the density of neurite networking in granule cells treated with a commercial wheat flour extract ( $5 \mathrm{mg}$ ), was comparable to those of untreated neuronal cell cultures (Fig. $2 c$ ).

The potencies of various cycad flour extracts relative to extracts of household flour are listed in Table 1. Neither 6-cyano7-nitroquinoxaline-2,3-dione (CNQX) nor MK-801 (1 $\mu \mathrm{M})$ protected the granule cells against the neurotoxicity elicited by the neurotoxic flour extracts (Fig. 3), and the BMAA concentration in culture dishes was calculated to be less than $5 \mu \mathrm{M}$ (Table 1). Synthetic BMAA required $5 \mathrm{~d}$ at a concentration of $2 \mathrm{~mm}$ to kill $95 \%$ of the granule cells in culture medium containing 26 $\mathrm{mm}$ bicarbonate (Weiss et al., 1988). Under these conditions, addition of MK-801 $(1 \mu \mathrm{M})$ completely protected the cerebellar neurons from the excitotoxic actions of BMAA (data not shown). Exposure of neuronal cultures to extracts equivalent to very high amounts of commercial wheat flour (i.e., $100 \mathrm{mg}$ ), or cycad female gametophyte tissue (i.e., $50 \mathrm{mg}$ ), did produce neuronal degeneration (see Table 1); however, MK-801 (1 $\mu \mathrm{M})$ did not protect against the neurotoxic response on neuronal elements or disruption of neurite networking (data not shown).

One of the potent neurotoxic flour extracts (i.e., from Umatac) was studied in an attempt to isolate and identify the toxic constituent(s). An acidic extract of this sample was thoroughly backextracted with dichloromethane in an attempt to extract the toxic component into the organic phase. However, toxicity remained in the aqueous layer. Similarly, when the $\mathrm{pH}$ of the extract was made acidic ( $\mathrm{spH} 2)$ or basic $(\geq \mathrm{pH} \mathrm{10)}$ and then reextracted with dichloromethane, toxicity still resided with the aqueous layer. Acid hydrolysis of toxic extracts reduced neither BMAA content nor toxicity. Likewise, freezing did not affect the toxicity of the extract. Therefore, cationic species were examined in four selected extracts (i.e., one extract of $C$. circinalis 
a

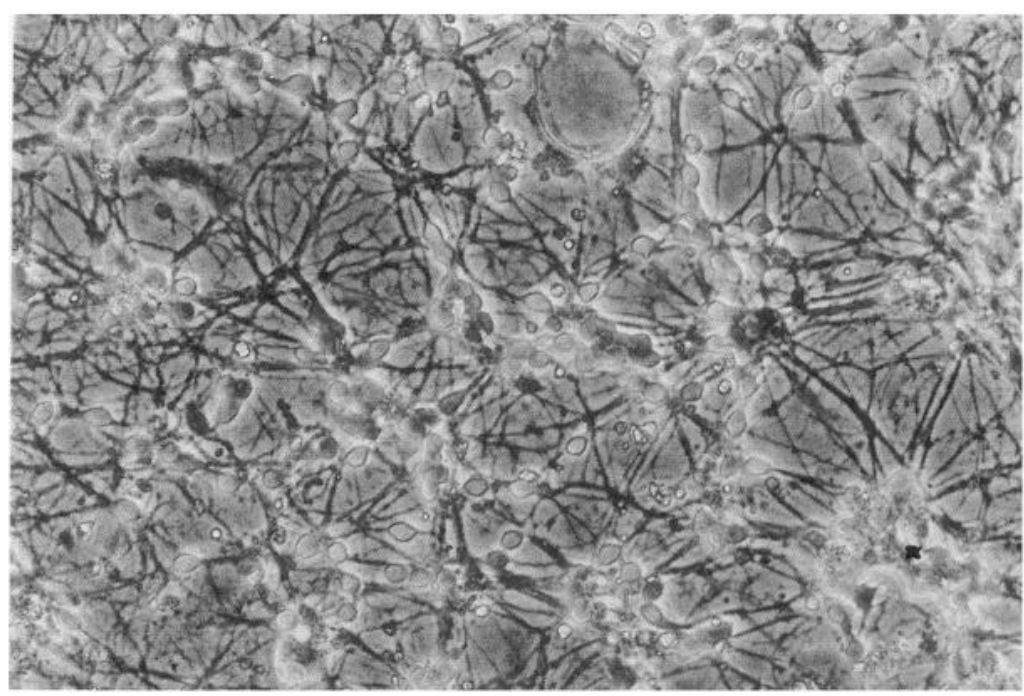

b

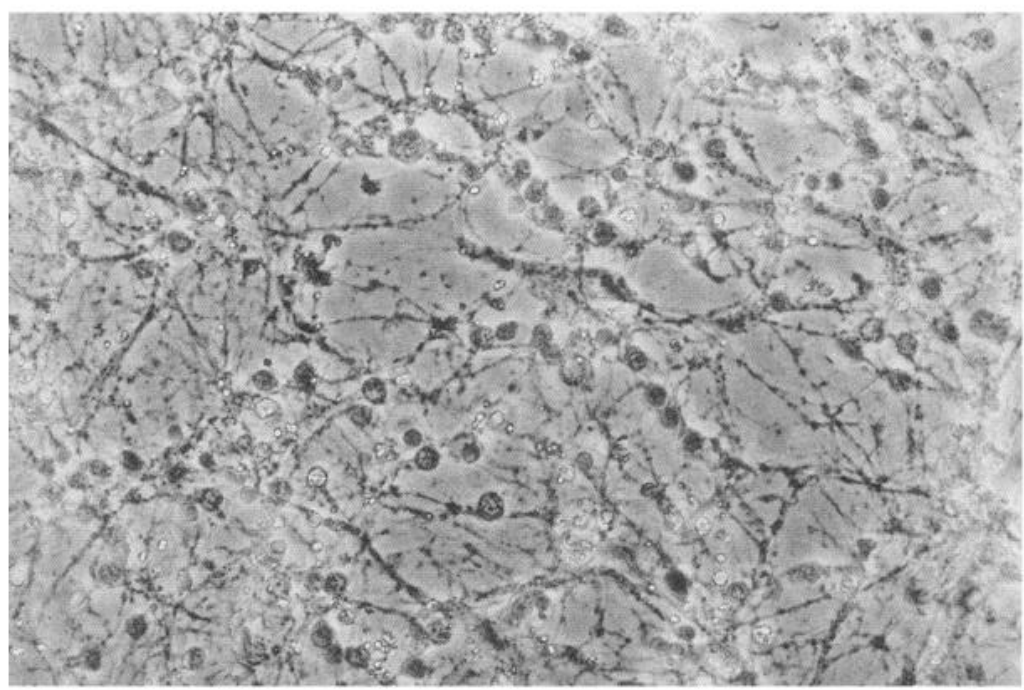

C

Figure 1. The neurotoxicity of Guamanian cycad flour on cultured cerebellar granule cells. Phase-contrast micrographs of the following: $a$, untreated cerebellar granule cell culture (DIV 10); $b$, cerebellar granule cells on DIV 10 after treatment with the equivalent of $5 \mathrm{mg}$ of Guamanian flour for $6 \mathrm{hr} ; c$, cerebellar granule cells on DIV 10 after treatment with the equivalent of $5 \mathrm{mg}$ of commercial wheat flour for $6 \mathrm{hr}(400 \times)$.

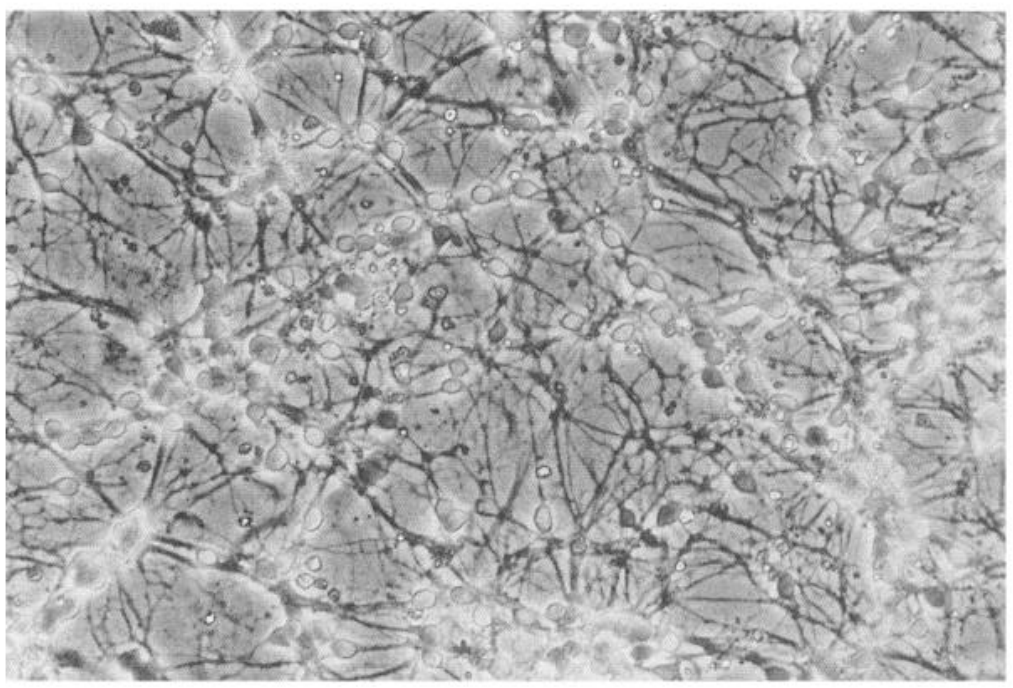


a

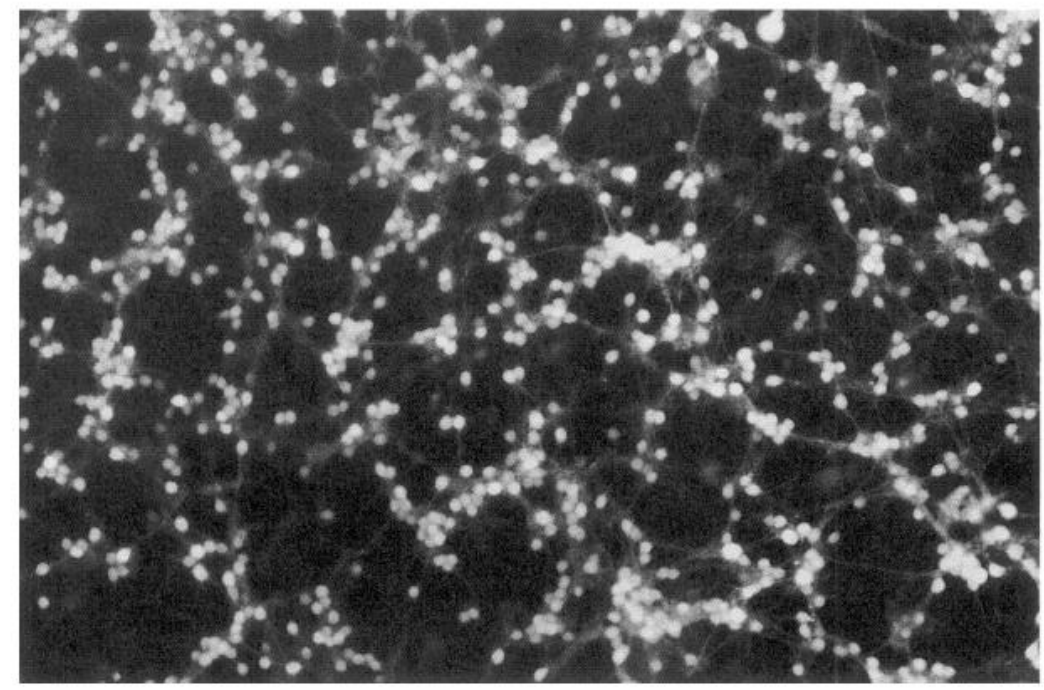

b

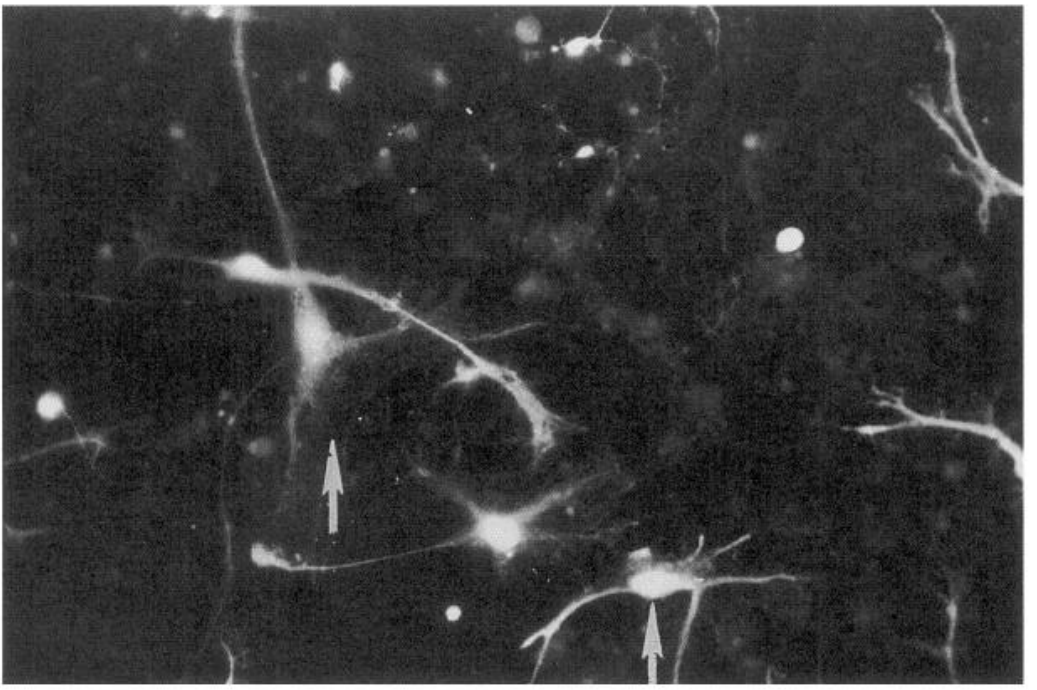

C

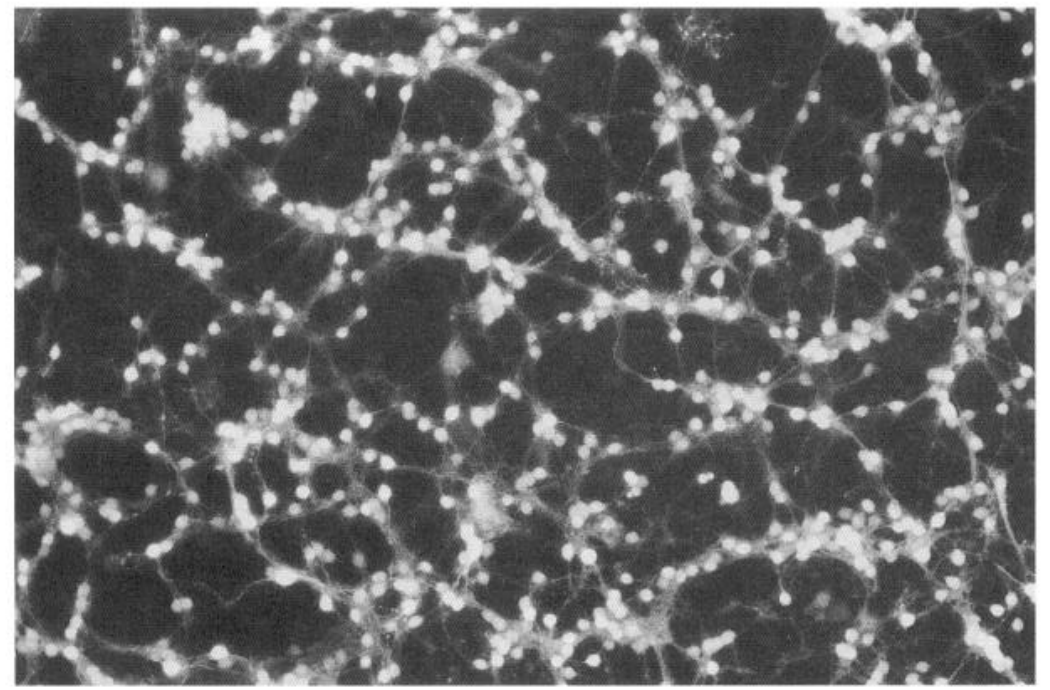

Figure 2. Fluorescein diacetate staining of cultured cerebellar granule cells in the presence or absence of the neurotoxic Guamanian cycad flour extract. $a$, Untreated; $b$, after treatment with the equivalent of $5 \mathrm{mg}$ of Guamanian cycad flour for $24 \mathrm{hr}$; $c$, after treatment with the equivalent of $5 \mathrm{mg}$ of commercial wheat flour for $24 \mathrm{hr}(140 \times)$. Arrows indicate astrocytes. 


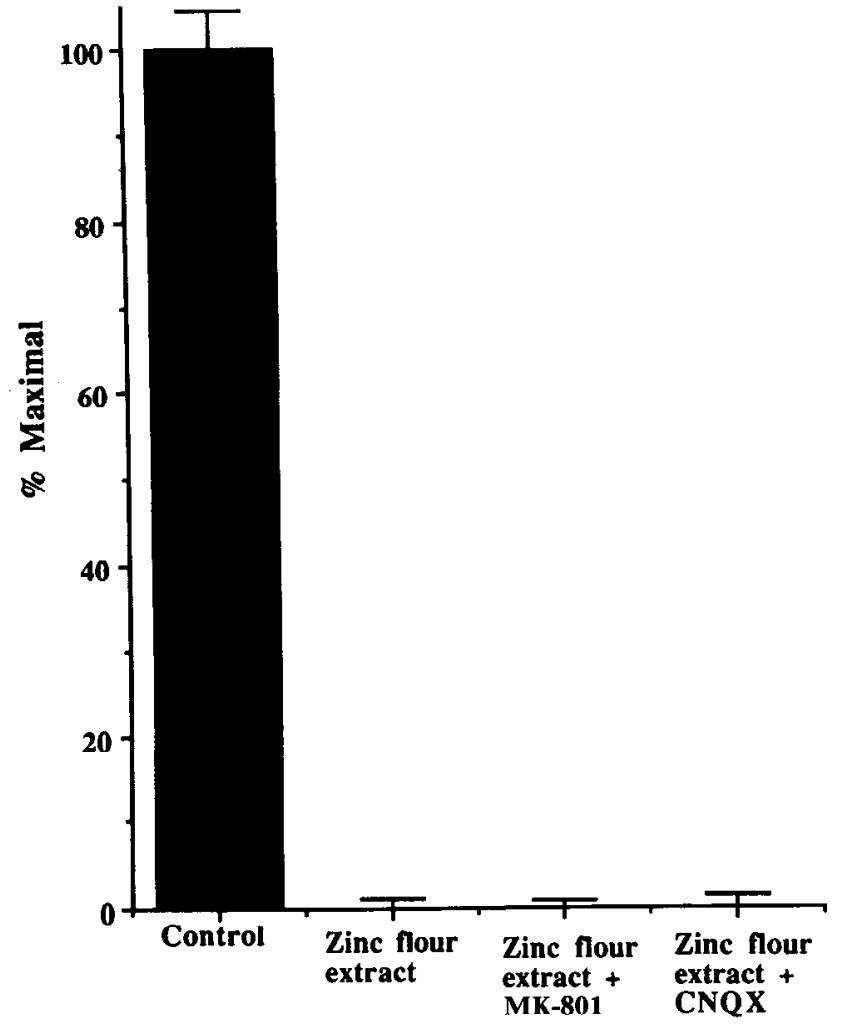

Figure 3. Lack of effect of MK- 801 and CNQX on the neurotoxicity of zinc-containing flour extracts. Cerebellar granule cells (DIV 14) were exposed to the equivalent of $5 \mathrm{mg}$ of zinc-containing flour extract alone, or in the presence of MK-801 $(1 \mu \mathrm{M})$ or CNQX $(50 \mu \mathrm{M})$. After $24 \mathrm{hr}$, the cells from control cultures ( 300 cells counted) and from culture dishes containing the zinc flour extract with and without the added antagonists were counted using phase-contrast microscopy. CNQX was prepared in dimethyl sulfoxide (DMSO) such that the medium concentration was 5\%. DMSO (5\%) elicited no deleterious effect on the cultured neurons. The results are expressed as percent maximal $\pm S E M$. Identical results were obtained when the zinc-containing flour extract was replaced with pure zinc $(100-140 \mu \mathrm{M})$ using the same concentrations of antagonists.

female gametophyte tissue, one of the highly toxic processed cycad flour, a second prepared from relatively nontoxic processed cycad flour, and wheat flour) by DC arc spectrography. This semiquantitative approach indicated no significant differences between toxic and nontoxic extracts for most cations; however, significantly higher levels of zinc were evident in the toxic cycad flour extract.

To confirm this finding, precise ICP spectrometry was used to analyze these same four extracts for aluminum, manganese, zinc, arsenic, cadmium, lead, and selenium. The extracts were aspirated directly into the ICP, which was calibrated using pure elemental standards. The major difference among the extracts was a highly significant excess in the zinc content in the toxic washed cycad flour sample (see Table 2). The amount found was $360 \mu \mathrm{g}$ of $\mathrm{Zn} / \mathrm{ml}$ of extract. If we assume complete zinc extraction of $1 \mathrm{gm}$ of flour into $10 \mathrm{ml}$ of solution, the calculated zinc level in the flour is $3.6 \mathrm{mg} / \mathrm{gm}$. Table 2 also indicates that the zinc content in unprocessed cycad flour was comparable to the levels found in commercial wheat flour. To verify that excess levels of zinc were not introduced during our extraction procedure, multiple samples of toxic and nontoxic flours $(n=21)$ were analyzed directly by ICP after completely dissolving the
Table 1. BMAA content and relative toxicities to cerebellar granule cells of some cycad flour samples

\begin{tabular}{|c|c|c|}
\hline Sample & $\begin{array}{l}\text { Potency } \\
\text { of extract }\end{array}$ & $\operatorname{BMAA}(\mu \mathrm{M})$ \\
\hline Household wheat flour (USA) ${ }^{b}$ & 1.0 & $\mathrm{ND}^{c}$ \\
\hline \multicolumn{3}{|l|}{ Female gametophyte extracts } \\
\hline C. circinalis (Umatac) ${ }^{b}$ & 1.1 & 182 \\
\hline C. revoluta (from Florida) & 1.1 & 40 \\
\hline C. media (from Florida) & 1.6 & 48 \\
\hline \multicolumn{3}{|l|}{ Processed cycad flour extracts } \\
\hline Yigo $^{d}$ & $>20$ & $<5$ \\
\hline Merizo $^{d}$ & $>20$ & $<5$ \\
\hline $\mathrm{Umatac}^{b, d}$ & $>20$ & $<5$ \\
\hline Agat $^{e}$ & $\approx 2.0$ & $<5$ \\
\hline All others & $<1.0$ & $0-50$ \\
\hline
\end{tabular}

Flour extracts were prepared as dctailcd clscwherc (Duncan et al., 1990). The dried residue from the extraction process was reconstituted in culture medium and a given volume (10-100 $\mu \mathrm{l})$ added to neurons after $3 \mathrm{~d}$ in culture

a Potency of flour extract was defined as $100 \times$ the inverse of the minimum amount of flour (expressed as mg added to culture dish) that had to be extracted into 0.1 $\mathrm{M} \mathrm{HCl}$ to cause toxicity (i.e., defined as cell death) when added to the neurons in culture. The corresponding concentration of BMA $\Lambda$ was obtained by calculation from the BMAA content of an equivalent mass of flour.

${ }^{b}$ These samples, plus one of those randomly selected from "All others," were examined by DC arc emission spectrography and ICP spectrometry; see results in Table 2.

c ND, Not detected.

${ }^{d}$ Zinc content of these flour samples was $\approx 3.8 \mathrm{mg} / \mathrm{gm}$.

' Zinc content of this flour sample $\approx 0.5 \mathrm{mg} / \mathrm{gm}$.

solid flour samples. Results ranged from 0.02 to $3.9 \mathrm{mg} / \mathrm{gm}$. The zinc content of three cycad flour samples was approximately $3.8 \mathrm{mg} / \mathrm{gm}$, one sample had intermediate zinc levels (i.e., $\approx 0.5$ $\mathrm{mg} / \mathrm{gm}$ ), and seven of the remaining cycad flours had zinc levels between 0.03 and $0.20 \mathrm{mg} / \mathrm{gm}$. No zinc was detected in the other nontoxic cycad flours or commercial wheat flour.

Because of the very high zinc content of the toxic flour extract, we proceeded to determine whether this metal was the toxic agent. Neurotoxicity of extracts was found to correlate with zinc content; that is, the most toxic samples all had the highest zinc content. Exposure to zinc chloride $(100 \mu \mathrm{M})$ for $6 \mathrm{hr}$ caused cerebellar granule cell degeneration and neurite disruption (Fig. $4 a)$. Addition of EDTA $(200 \mu \mathrm{M})$ protected against the neurotoxicity (Fig. $4 b)$, and EDTA $(200 \mu \mathrm{M})$ alone elicited no apparent effects on the culture (compare Figs. $4 c$ and $1 a$ ). Fluorescein

Table 2. Quantitative analysis of flour extracts by ICP spectrometry

\begin{tabular}{lllll} 
& $\begin{array}{l}\text { Unprocessed } \\
\text { cycad flour }\end{array}$ & $\begin{array}{l}\text { Nontoxic } \\
\text { processed } \\
\text { cycad flour }\end{array}$ & $\begin{array}{l}\text { Toxic } \\
\text { processed } \\
\text { cycad flour }\end{array}$ & $\begin{array}{l}\text { Household } \\
\text { wheat } \\
\text { flour }\end{array}$ \\
\hline $\mathrm{Al}$ & 1.1 & 1.3 & 1.3 & 1.6 \\
$\mathrm{Mn}$ & 0.69 & 0.26 & 0.57 & 0.57 \\
$\mathrm{Zn}$ & 0.99 & 0.55 & 360 & 0.76 \\
$\mathrm{As}$ & - & - & $<1$ & $\cdot$ \\
$\mathrm{Cd}$ & - & - & $<1$ & $\cdot$ \\
$\mathrm{Pb}$ & - & - & $<1$ & $\cdot$ \\
$\mathrm{Se}$ & - & - & $<1$ & $\cdot$
\end{tabular}

Flour samples were extracted into dilute $\mathrm{HCl}$, and a portion of the filtered supernatant was analyzed to obtain these results. All results are in $\mu \mathrm{g} / 100 \mathrm{mg}$ of flour. $\cdot=$ not assayed. 
a

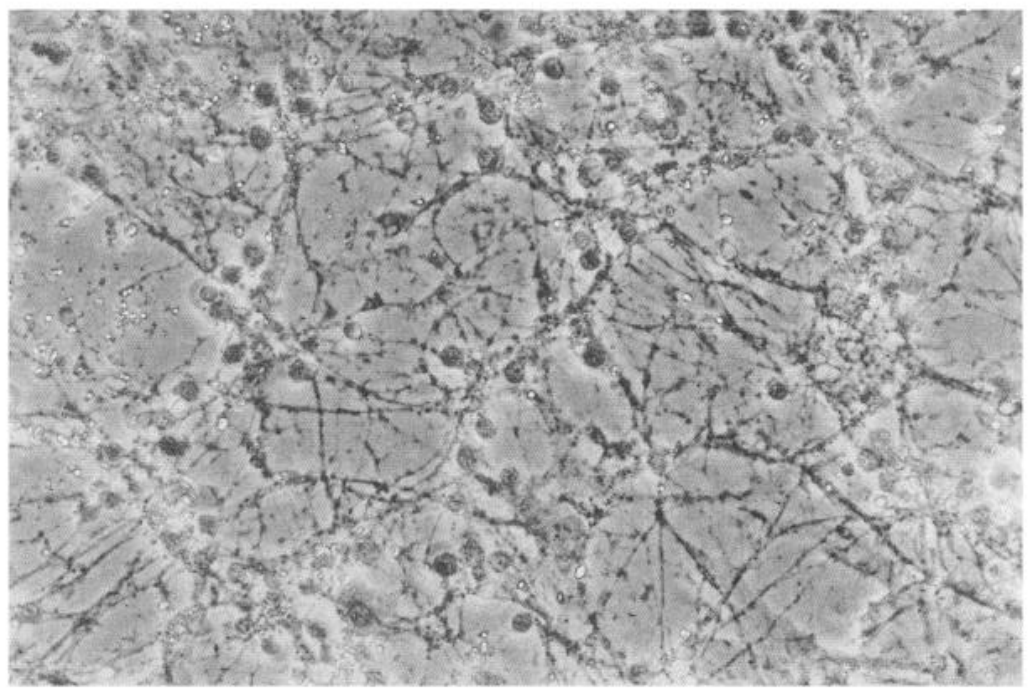

b

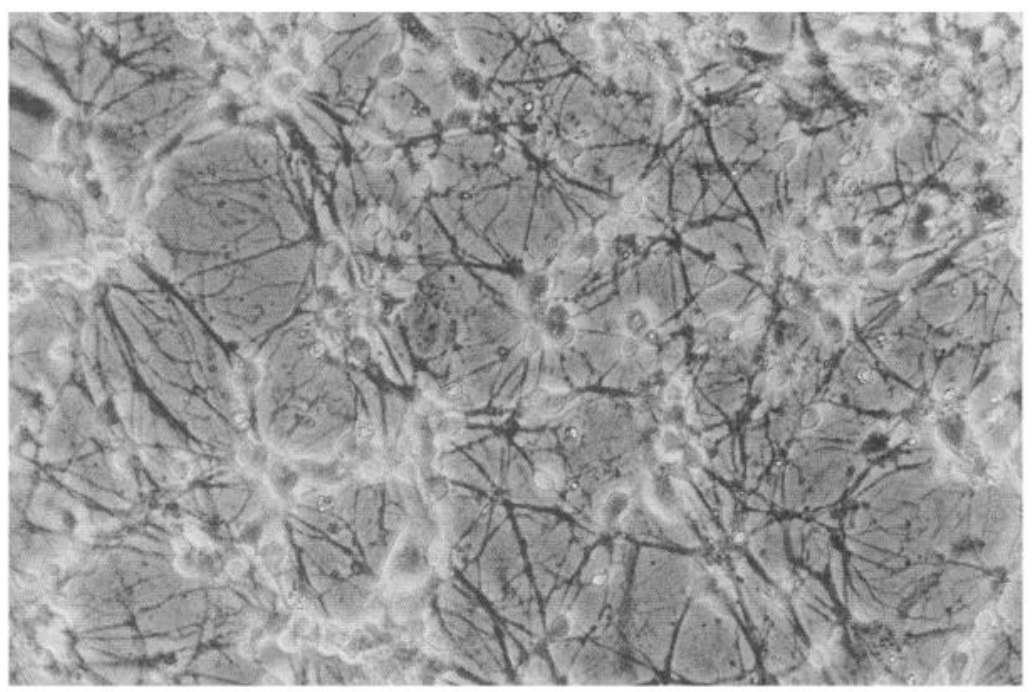

C

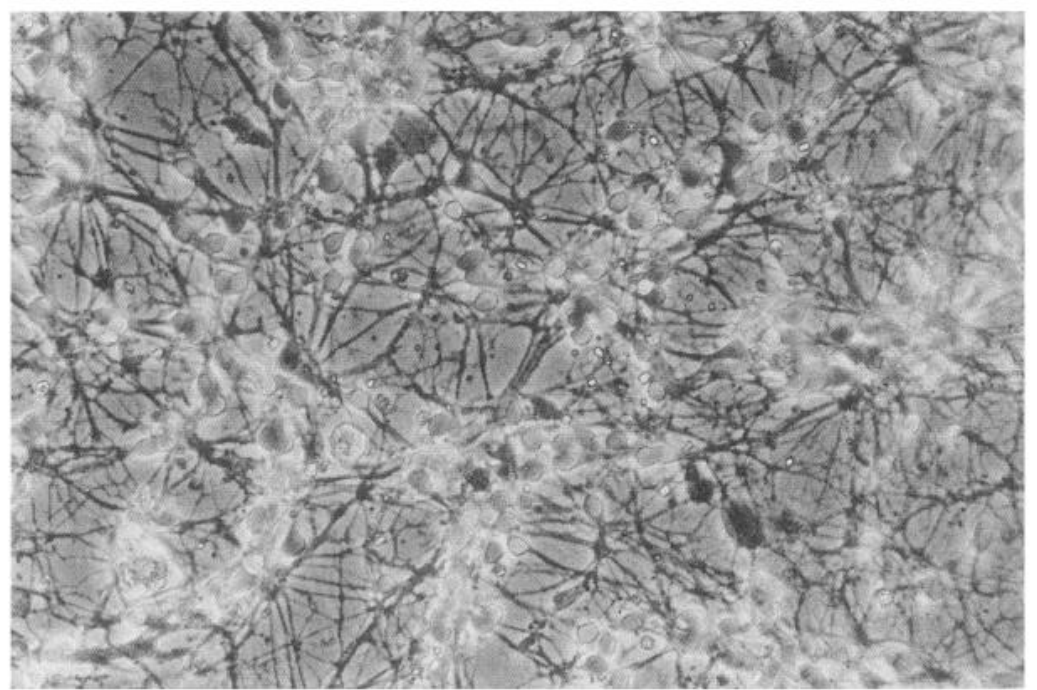

Figure 4. Phase-contrast micrographs of cerebellar granule cells treated with zinc chloride and protection by EDTA: cerebellar granule cells on DIV 10 after treatment with the following: $a$, zinc chloride $(100 \mu \mathrm{M})$ for $6 \mathrm{hr} ; b$, zinc chloride $(100 \mu \mathrm{M})$ and EDTA $(200 \mu \mathrm{M})$ for $6 \mathrm{hr} ; c$, EDTA $(200 \mu \mathrm{M})$ for $6 \mathrm{hr}(400 \times)$. 
a

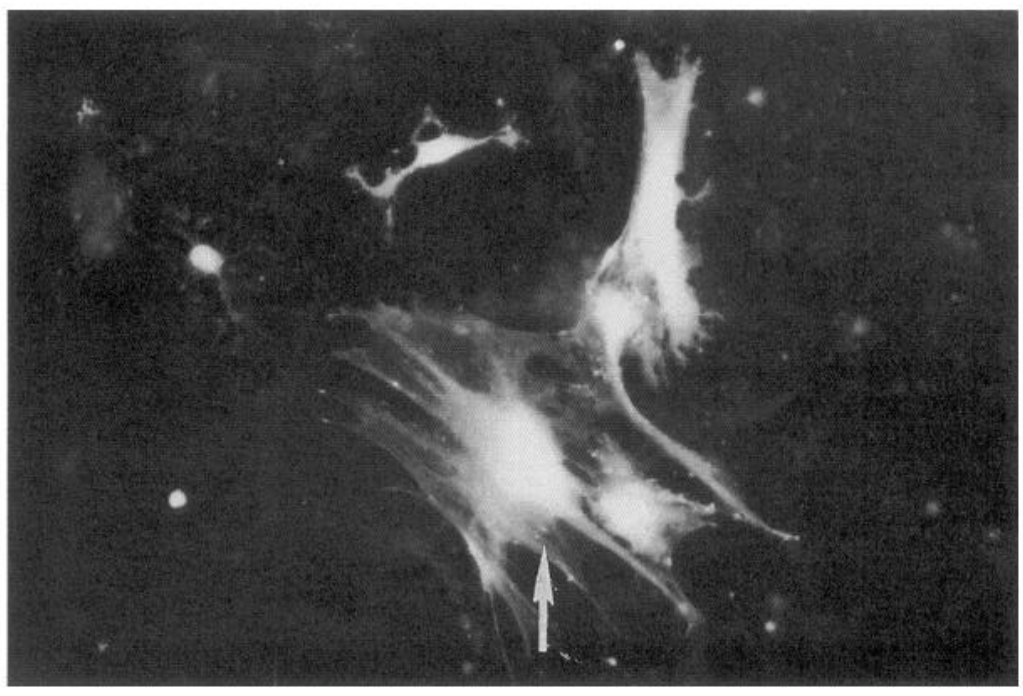

b

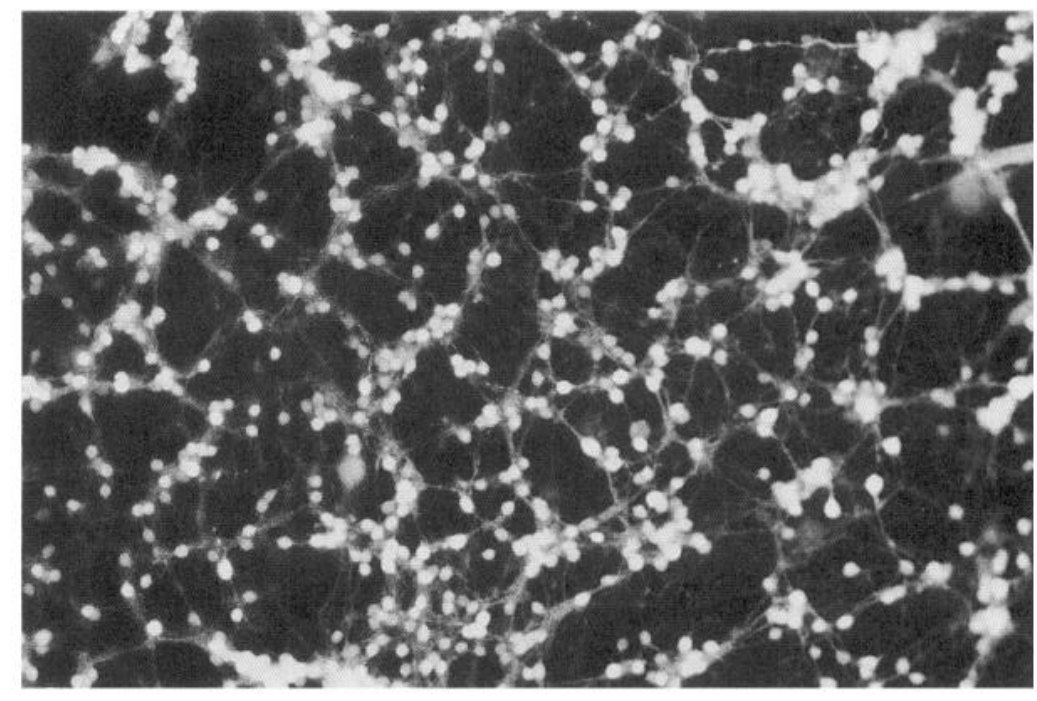

C

Figure 5. Fluorescein diacetate staining of cerebellar granule cells treated with zinc chloride: cerebellar granule cells on DIV 10 after treatment with the following: $a$, zinc chloride $(100 \mu \mathrm{M})$ for $24 \mathrm{hr} ; b$, zinc chloride $(50 \mu \mathrm{M})$ for $24 \mathrm{hr} ; c$, zinc chloride (75 $\mu \mathrm{M}$ ) for $72 \mathrm{hr}$ $(140 \times)$. Arrows indicate astrocytes.

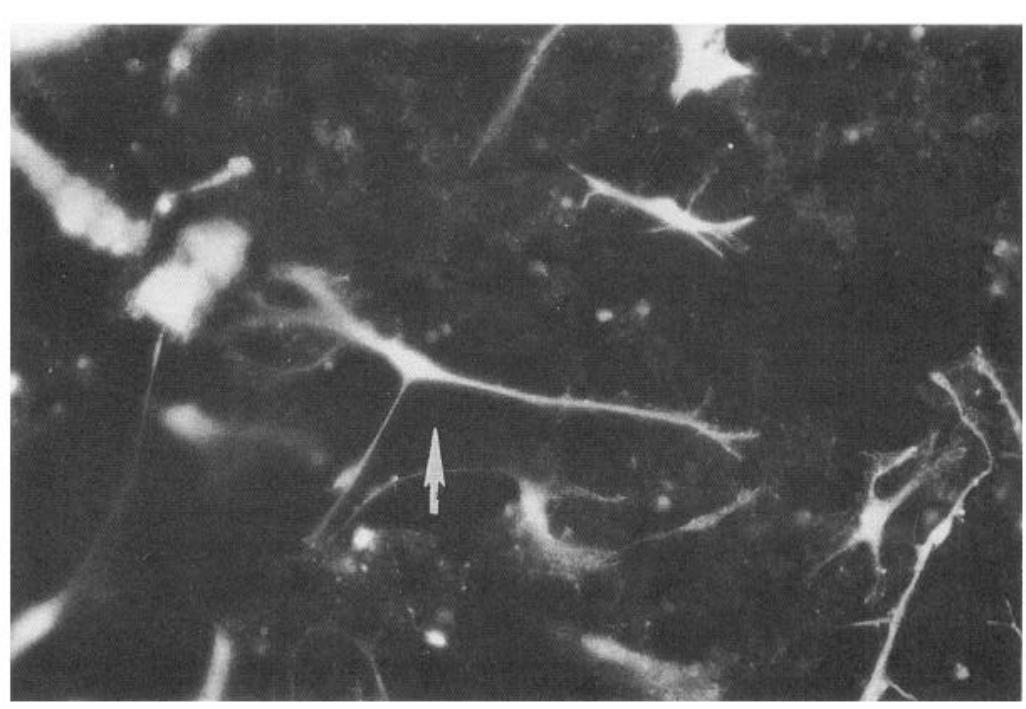


diacetate staining of cerebellar granule cell cultures treated with zinc chloride $(100 \mu \mathrm{M})$ confirmed the finding that zinc is neurotoxic (Fig. 5a). Astrocytes remained brilliantly fluorescent; similar results were observed after cerebellar granule cell cultures were exposed to the neurotoxic flour extract for the same period (compare Figs. $5 a$ and $2 b$ ). No toxicity was observed when neurons were treated with $50 \mu \mathrm{M}$ zinc chloride for $24 \mathrm{hr}$ (compare Figs. $5 b$ and $2 a$ ). Exposure of cerebellar granule cell cultures to zinc chloride $(75 \mu \mathrm{M})$ for $3 \mathrm{~d}$ did not affect astrocyte fluorescence, although virtually all the neuronal elements were destroyed (Fig. 5c). The concentration dependence and time dependence of zinc on cultured cerebellar granule cells is shown in Table 3. Whereas $100 \mu \mathrm{M}$ zinc killed neurons within $24 \mathrm{hr}$ during early culture times, at later culture times ( $>$ DIV 8 ), only $6 \mathrm{hr}$ was required to destroy the neurons. Lower zinc concentrations elicited no effect on the cells regardless of when the zinc was added. Neither MK-801 (1 $\mu \mathrm{M})$ nor CNQX (50 $\mu \mathrm{M})$ afforded protection against zinc toxicity $(100 \mu \mathrm{M})$ (see Fig. 3 caption).

When toxic flour extracts and EDTA were added simultaneously to cerebellar granule cells in culture, toxicity was abolished (Fig. $6 a$ ). The addition of EDTA to the commercial flour (same concentration) caused no apparent effect (Fig. 6b). Furthermore, toxic flour extracts, pretreated with ammonium sulfide to precipitate metals as their insoluble sulfides, were no longer toxic when added to cerebellar granule cells in culture (Fig. 6c). An extract of commercial wheat flour taken through the ammonium sulfide procedure elicited no deleterious effects on the cultured granule cell neurons (Fig. $6 d$ ).

Concentration-toxicity relationships for the four zinc-containing flour extracts gave an $\mathrm{LC}_{95}$ between 73 and $146 \mu \mathrm{M}$ based upon the known zinc concentrations. These calculated concentrations are comparable to those required to destroy the cultured neurons by addition of pure zinc chloride (see Table 3 ).

\section{Neurotoxicity testing in mesencephalic cultures}

The results outlined above led us to consider the effects of zinc (the putative neurotoxic agent) on other neurons. Because cerebellar degeneration is not a prominent neuropathological feature of ALS-PD, we examined the effects of one neurotoxic flour extract (i.e., from Umatac) on ventral mesencephalic cultures, a brain region that does undergo neuropathological changes in this disorder (Hirano et al., 196la,b; Yamamoto and Hirano, 1985). The typical appearance of ventral mesencephalic cultures, a heterogeneous cell culture, after fixation and immunocytochemical staining for $\mathrm{TH}$ is shown in Figure $7 a$. Numerous neuronal cell bodies and neurite networking are prominent. Typically, about $1 \%$ of the population stains positive for $\mathrm{TH}$, a marker for the dopaminergic neurons (Berger et al., 1982). Extracts equivalent to $1.5 \mathrm{mg}$ of the toxic flour elicited no neurotoxicity within $24 \mathrm{hr}$; however, doubling the amount of extract added produced rapid disintegration of neurite networking and neuronal elements (Fig. $7 b$ ). Dopamincrgic ncurons were not selectively destroyed by the addition of the toxic flour. Morphologic criteria and cell number (Fig. 7c) indicated that astrocytes were not affected; astrocytes remained unaffected in cerebellar granule cell cultures when treated with the toxic flour extract (see Fig. 2b). Addition of an extract of a comparable amount of commercial wheat flour to ventral mesencephalic cultures produced no neurotoxicity (Fig. 7d).

Cultured ventral mesencephalic cells were exposed to various concentrations of pure zinc chloride. Neuronal disintegration and disruption of neurite networking were prominent within 24
Table 3. Differential effect of zinc on cultured cerebellar granule cells

\begin{tabular}{|c|c|c|c|c|}
\hline \multirow{2}{*}{$\begin{array}{l}\text { Concen- } \\
\text { tration } \\
(\mu \mathbf{M}) \\
\end{array}$} & \multirow{2}{*}{$\begin{array}{l}\text { Days } \\
\text { in vitro } \\
\text { zinc added }\end{array}$} & \multirow{2}{*}{$\begin{array}{l}\text { Days } \\
\text { in vitro } \\
\text { cells } \\
\text { examined }\end{array}$} & \multicolumn{2}{|c|}{ Response to zinc } \\
\hline & & & $\begin{array}{l}\text { Neurite } \\
\text { disruption }\end{array}$ & $\begin{array}{l}\text { Cell } \\
\text { death }(\%)\end{array}$ \\
\hline 10 & 5 & 6 & - & - \\
\hline 25 & 5 & 6 & - & - \\
\hline \multirow[t]{2}{*}{50} & 5 & 6 & - & - \\
\hline & 10 & 11 & - & - \\
\hline \multirow[t]{2}{*}{75} & 5 & 6 & + & $>95$ \\
\hline & 10 & $10^{a}$ & + & 50 \\
\hline \multirow[t]{2}{*}{100} & 5 & 6 & + & $>95$ \\
\hline & 10 & $10^{a}$ & + & $>95$ \\
\hline
\end{tabular}

Cerebellar granule cells were prepared as outlined in Materials and Methods. Zinc chloride $(10-100 \mu \mathrm{M})$ was added on DIV 5 or 10 and the cells examined for neurotoxic effects on DIV 6,10 , and 11. Neurotoxic effects included neurite disruption and neuronal cell death. Percentage cell death was calculated as indicated in Table 1. Values represent the mean, in percent, of three comparable fields of zinc-treated and untreated control cultures. Only neurons that were phase bright and refractive to light were considered viable. In untreated control cultures, 200 viable cells were counted. Experiments were performed in triplicate using three different batches of neurons.

${ }^{a}$ Examinations of cultures $6 \mathrm{hr}$ after addition of zinc chloride.

hr when $100 \mu \mathrm{M}$ zinc chloride was added to ventral mesencephalic cultures (Fig. $8 a$ ). Zinc did not selectively destroy the dopaminergic neurons but was neurotoxic to all neuronal elements. The addition of EDTA $(200 \mu \mathrm{M})$ to the culture containing zinc chloride $(100 \mu \mathrm{M})$ conferred complete protection against the neurotoxic effects of zinc (Fig. $8 b$ ). EDTA alone elicited no apparent effect on the culture compared to untreated control cultures (Figs. 7a, 8c). The identical toxicity-concentration relationship was observed when zinc chloride was added to ventral mesencephalic cultures for either 6 or $12 \mathrm{~d}$; that is, the sensitivity of these neurons to a given zinc chloride concentration did not change with time in culture (data not shown).

In mesencephalic cultures, EDTA afforded complete protection against the neurotoxic effects of the toxic flour extract (Fig. $8 d$ ). No toxicity was observed when either EDTA or commercial wheat flour was added to ventral mesencephalic cultures (Fig. $8 e)$.

\section{Zinc uptake into cycad female gametophyte tissue}

To determine whether zinc could be introduced during processing, we soaked chips of fresh $C$. circinalis female gametophyte tissue in water in a galvanized iron bucket. This resulted in uptake of zinc by the plant tissue. Increasing the soaking period increased the total zinc content. After $7 \mathrm{~d}$ of soaking, flour prepared from the washed chips contained $1.2 \mathrm{mg} / \mathrm{gm}$ of zinc as determined by ICP.

\section{Discussion}

Guamanian ALS-PD is a neurodegenerative disorder characterized by diffuse skeletal muscle wasting and corticospinal tract dysfunction (amyotrophic lateral sclerosis), together with extrapyramidal motor dysfunction (parkinsonism) and dementia (Hirano et al., 1961a,b). Cycads (particularly members of the genus $($ ycas) have been considered a possible etiologic factor in this disorder, but it has proved difficult to find evidence to support this proposal. Cycas circinalis (Guam) and Cycas re- 


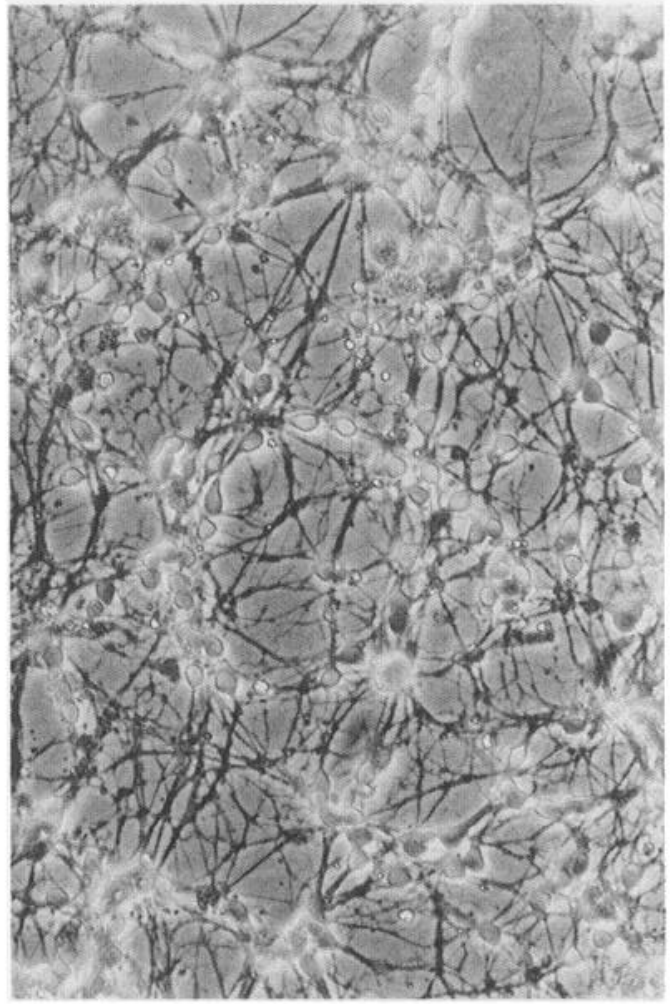

○

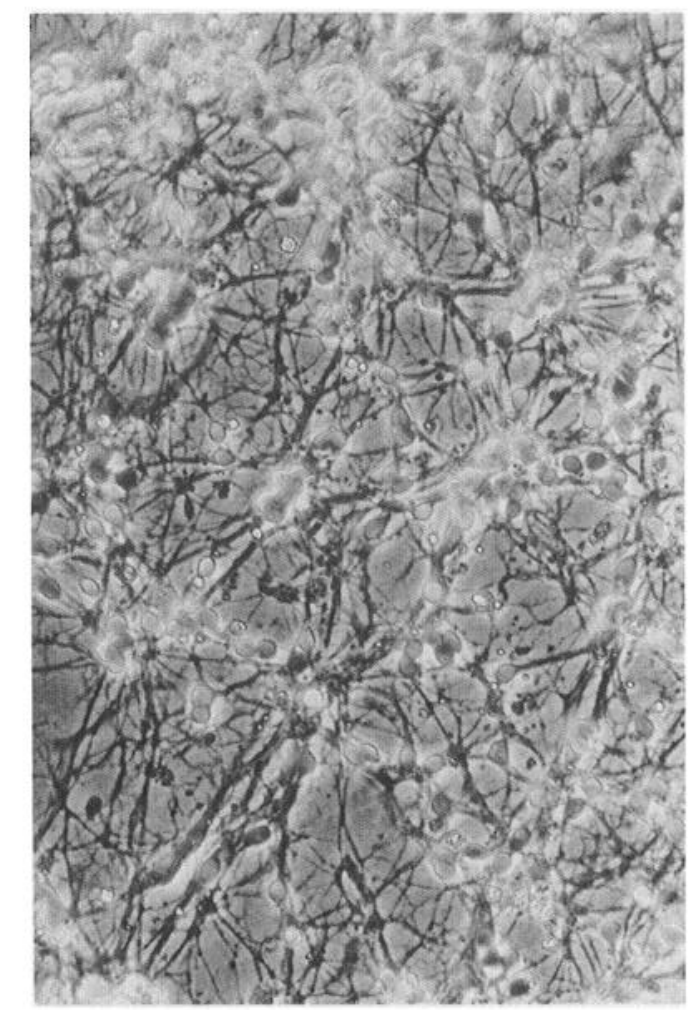

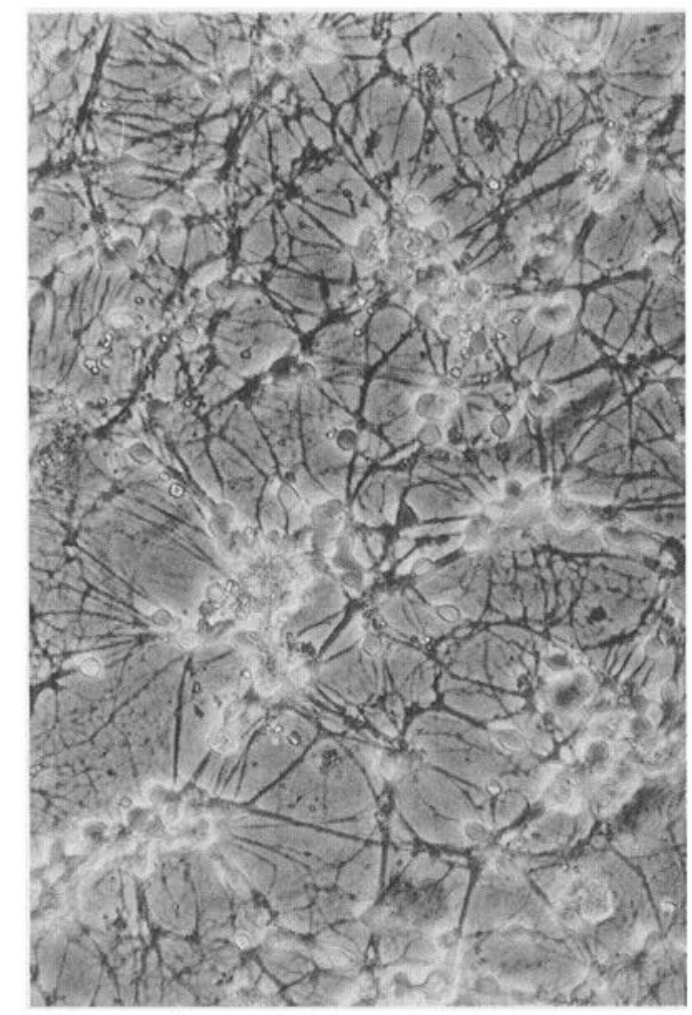

0

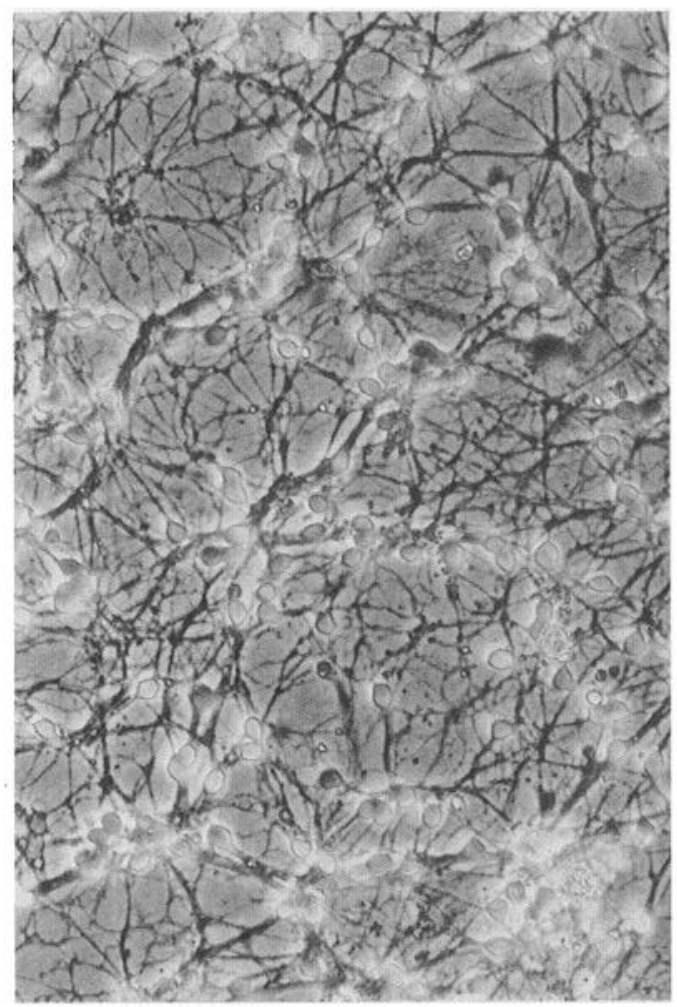

0
号 范

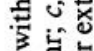

동ㅎㅁ

g

⿶.

๘ั0

우요

웡

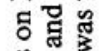

눙

J

吅

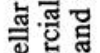

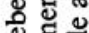

额

प्र क क

耀

를

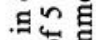

낭의

울 혀예

of

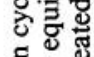

원

है

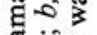

도 혀

4 号

突退突

응

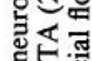

욤

ธ대당

कृ 5

ज्ञ

ㅌ. 둥

를 동

을 뭉

․․ㄹ

额

$\varangle$

둥 둥

낭 에 당

品政

这政

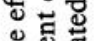

है

政

움형

㱒

F o ब

施当空

ㄴ. 웡워

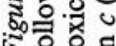



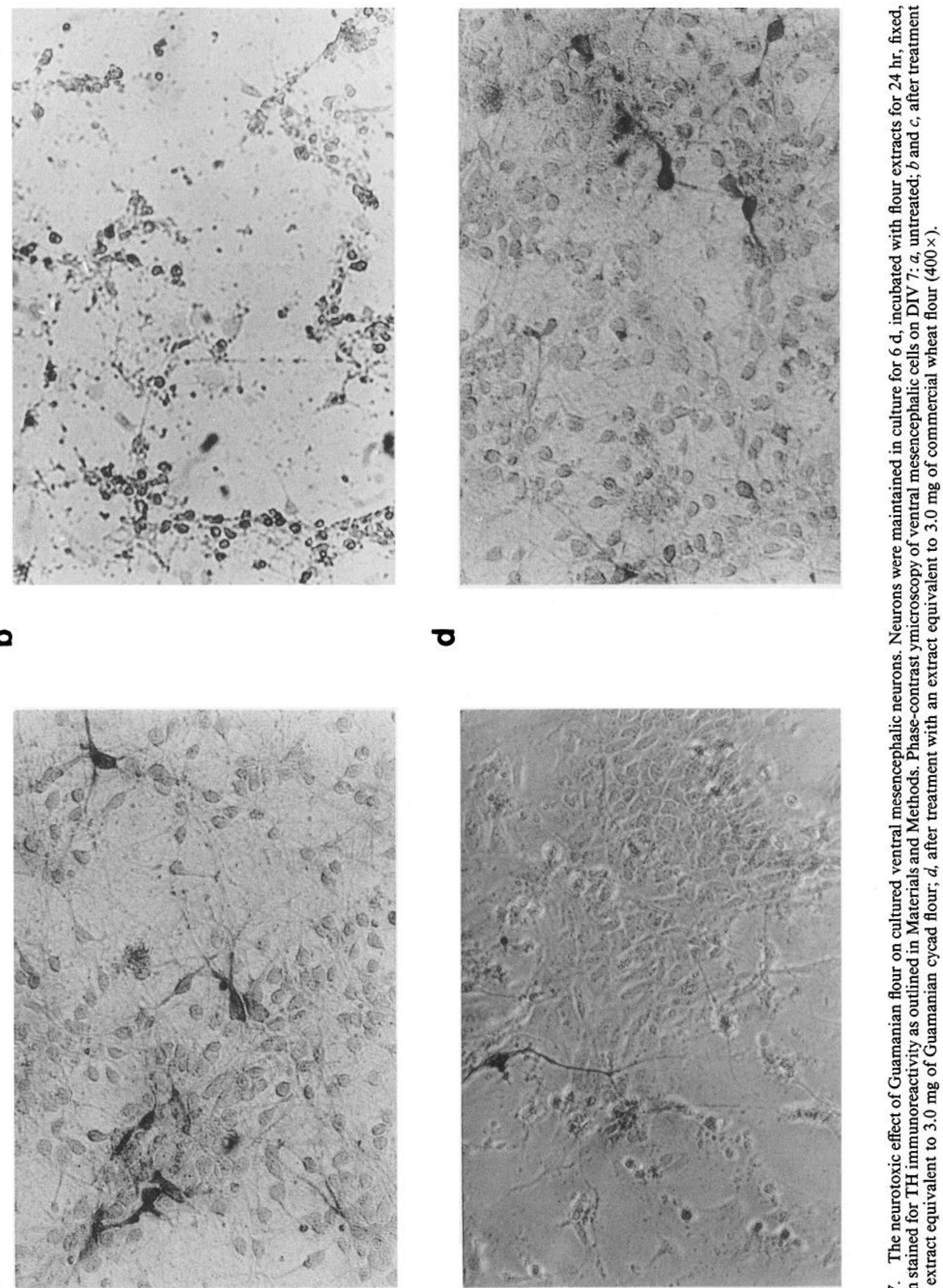

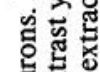

ํํㅇำ

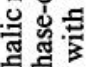

웅

㑏

医密

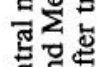

䘽

a

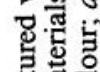

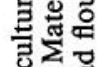

ㄷ.5

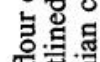

ธี

矛路

ㅋ.

矛哈

4

응

웡요

웅혀

要

氙递

氙总

.

놇

总完零 
a

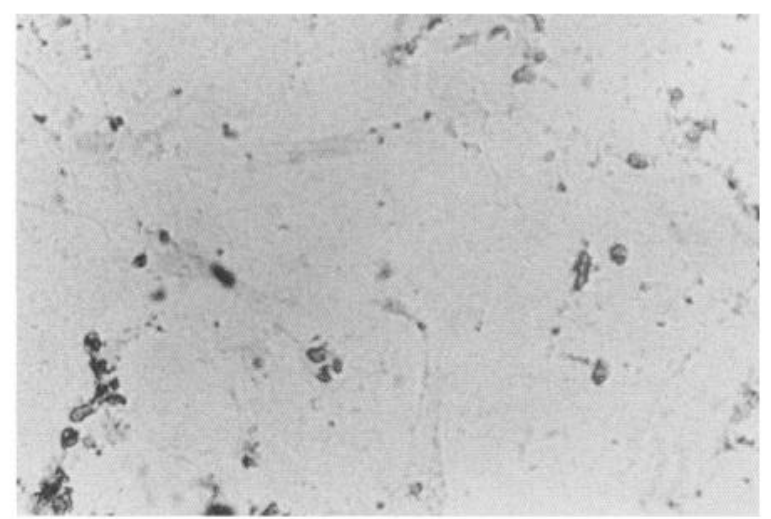

C

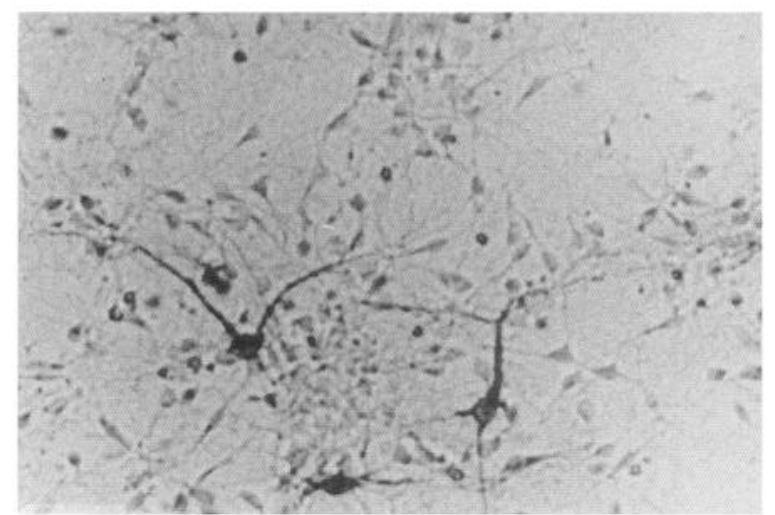

b

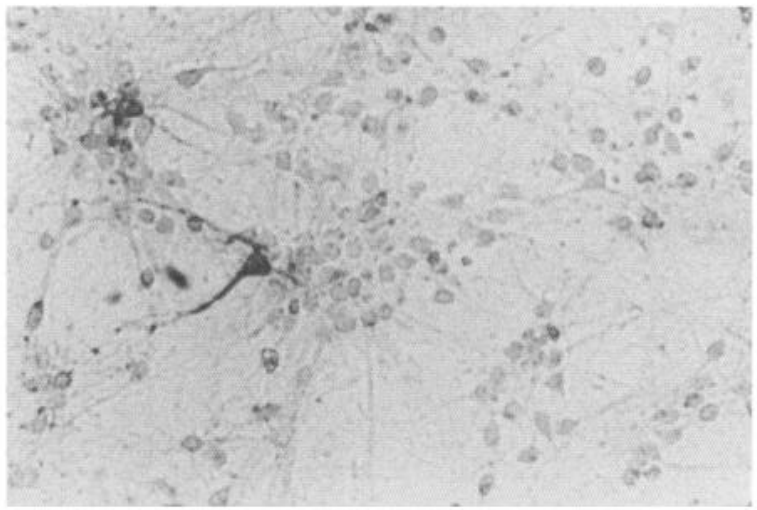

d

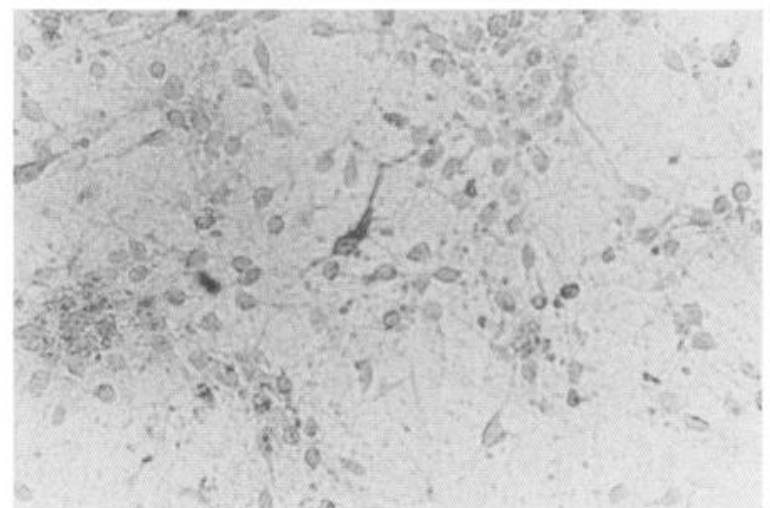

e

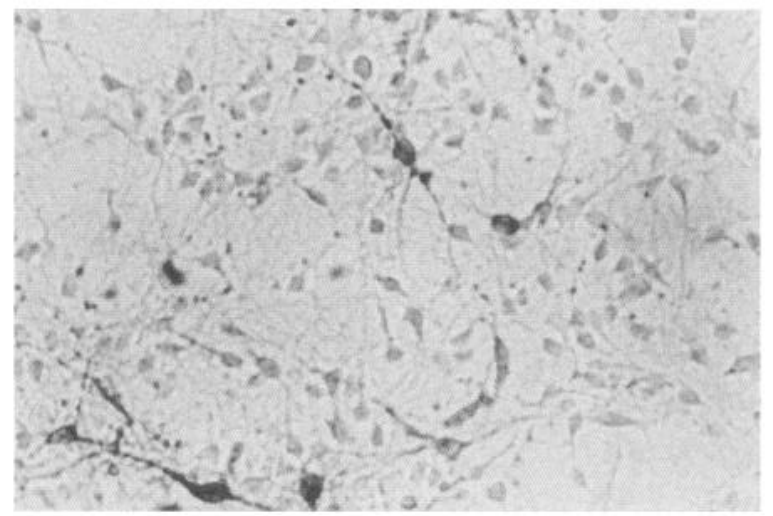

Figure 8. The protective effects of EDTA on the neurotoxicity of zinc chloride and Guamanian cycad flour on ventral mesencephalic cells. Phasecontrast microscopy of ventral mesencephalic cultures on DIV 7 after treatment with the following: $a$, zinc chloride (100 $\mu \mathrm{M})$ for $24 \mathrm{hr} ; b$, zinc chloride $(100 \mu \mathrm{M})$ and EDTA $(200 \mu \mathrm{M})$ for $24 \mathrm{hr} ; c$, EDTA $(200 \mu \mathrm{M})$ for $24 \mathrm{hr} ; d$, the equivalent of $5 \mathrm{mg}$ of toxic Guamanian flour and EDTA (200 $\mu \mathrm{M})$ for $24 \mathrm{hr} ; e$, the equivalent of $5 \mathrm{mg}$ of commercial wheat flour and EDTA $(200 \mu \mathrm{M})$ for $24 \mathrm{hr}(400 \times)$.

voluta (Japan) have both been linked to the high incidence of ALS-PD in the western Pacific region (Spencer et al., 1987a,c), and an unidentified Cycas species has been implicated in the west New Guinea focus (Spencer et al., 1987b). However, the neurotoxin that may be involved has not yet been established. We have therefore searched for neurotoxic components of extracts derived from raw seeds (i.e., the gametophyte tissue) and from cycad flour prepared by Guamanians in the traditional manner (i.e., processed flour).

Extracts were prepared from the raw female gametophyte tissue of three cycads, C. circinalis, C. revoluta, and C. media, and these were tested in cerebellar granule cells. Female ga- metophyte tissue was prepared in these studies because it is this portion of the seed that is used in the preparation of cycad flour. Because recent studies implicate BMAA in ALS-PD (Spencer et al., 1987a), we paid particular attention to this compound in our initial work. At high concentrations, BMAA is thought to mediate its neurotoxic response via the NMDA receptor, so we tested the flour extracts in cerebellar granule cell neuron cultures because these neurons express both NMDA and non-NMDA receptors (Gallo et al., 1987). For example, in the presence of physiological concentrations of glucose and magnesium, glutamate is neurotoxic to cerebellar granule cells and its neurotoxic response can be blocked with MK-801 (Marini et al., 1989). 
When pure BMAA was added to cerebellar granule cells in a bicarbonate-containing medium, we found that a concentration of $2 \mathrm{~mm}$ elicited a neurotoxic response. This finding, combined with reports from murine cortical cell culture (Weiss et al., 1989) and neonatal mouse cortex explants (Ross et al., 1987), indicates that BMAA is not a potent toxin in cerebellar granule cells. However, as expected, neurotoxicity in cerebellar granule cells mediated by BMAA ( 2 mM) was blocked by MK- 801 .

Having determined BMAA toxicity to cerebellar granule cells, we then used this culture as a bioassay for testing the toxicity of various cycad samples. Dose-response curves prepared from cycad gametophyte extracts $(C$. circinalis, $C$. revoluta, and $C$. media) indicated that these samples were not significantly more toxic than the control, that is, extracts of commercial wheat flour (see Table 1). Although high amounts of either commercial wheat flour or female gametophyte tissue were neurotoxic to cerebellar granule cell cultures, BMAA cannot be implicated because (1) BMAA is not found in commercial wheat flour (Duncan et al., 1990), (2) the BMAA content in the tissue culture medium arising from the gametophyte extracts was 11-40-fold below the toxic concentration as determined by the addition of pure BMAA to the cultures, (3) of the extracts prepared from cycad seeds those with the lowest BMAA concentrations were the most toxic, and (4) MK-801 was not neuroprotective (see Table 1).

We then moved on to examine extracts prepared from processed $C$. circinalis flour in our cerebellar granule cell culture system. All 17 flour samples tested were obtained from villagers on Guam and were prepared by them in the traditional manner by "processing" the female gametophyte tissue of $C$. circinalis. Dose-response curves were prepared from extracts of each of the processed flour samples and tested in cultured neurons. Characterized by a sharp concentration-toxicity relationship, three extracts were found to be strikingly neurotoxic, and a fourth was less toxic. The three most toxic extracts elicited pronounced swelling of neuronal perikaryon and disintegration of neurites within $6 \mathrm{hr}$ of addition to the cerebellar granule neuronal culture. The fourth toxic extract exerted its neurotoxic effect within $24 \mathrm{hr}$ (data not shown). As was observed for the crude seed extracts, the neurotoxicity of these three processed flour samples was not mediated by BMAA. MK-801 did not block toxicity, and the BMAA concentration in the medium was approximately 3 orders of magnitude below the predetermined toxic concentration. Ventral mesencephalic cultures exposed to the same toxic extracts died within $24 \mathrm{hr}$. Hence, cerebellar granule cell cultures and ventral mesencephalic cultures were both susceptible to the neurotoxic constituent of the toxic flour extract.

Because BMAA did not appear to be responsible for mediating this response, efforts were directed toward identifying the neurotoxic agent(s). A peptide or protein was not responsible because hydrolysis conditions known to degrade peptide bonds did not abolish neurotoxicity. As the neurotoxic factor could not be extracted from the aqueous phase at acid, base, or neutral $\mathrm{pH}$, we considered the possibility that ionic species were involved. A qualitative survey of selected flour samples suggested an excess level of zinc in one of the neurotoxic flours. A quantitative analysis for metal ions of all 17 processed cycad flours showed an excess amount of zinc in the most neurotoxic extracts and a moderate zinc level in the intermediate neurotoxic extract. To determine if zinc could be the neurotoxin in the flour extracts, we tested pure zinc chloride on cerebellar granule cells and ventral mesencephalic cells in culture. Zinc toxicity was indistinguishable from the toxicity demonstrated by the neurotoxic flour extracts, and it too was characterized by a sharp concentration-toxicity relationship in both cell culture systems. In addition, cerebellar granule cells exhibited a time dependencetoxicity relationship; that is, neurons that had been in culture for longer times were more sensitive to the toxic effects of zinc. (This same phenomenon was evident also when the toxic extracts were tested.) The neurotoxic concentration of pure zinc chloride was found to be virtually identical to the calculated zinc concentration in the culture medium at the $\mathrm{EC}_{50}$ point of the toxicity-response curves generated from the flour extracts. In cerebellar granule cell cultures treated with either zinc or the toxic flour extracts, vital staining indicated that the astrocytes remained viable. Consistent with our hypothesis that zinc is the toxic constituent of the flour extracts, Borenfreund and Babich (1987) have shown that comparable zinc chloride concentrations (i.e., $100 \mu \mathrm{M}$ ) are toxic to murine neuroblastoma cells and to fibroblasts, but higher concentrations (i.e., $>200 \mu \mathrm{M}$ ) are required to kill astrocytes from neonatal rat brain. It has been shown that zinc is also neurotoxic to cortical neuronal cultures (Choi et al., 1988) and that zinc potentiates quisqualate toxicity (Koh and Choi, 1988). In fact, BMAA (3 mM) kills cortical neurons via NMDA (85\%) and non-NMDA (15\%) receptor activation (Weiss et al., 1989). It is possible, therefore, that zinc alone or in combination with BMAA kills granule cells by activation of quisqualate receptors. However, in our studies, it is unlikely that zinc alone or the combination of BMAA and zinc acting in concert kills the granule cells by activating quisqualate receptors because (1) the neurons are relatively insensitive to quisqualate (concentrations up to $1 \mathrm{~mm}$ for $24 \mathrm{hr}$ are not toxic; A. M. Marini, unpublished observations), (2) the non-NMDA receptor antagonist CNQX does not protect against the toxicity of pure zinc or zinc flour extracts, and (3) the neurotoxic zinc concentration using pure zinc chloride is virtually identical to the zinc concentration calculated to be present in the zinc flour extract. These data indicate that zinc itself is the operative neurotoxin in the zinc flour extracts. Therefore, the neurotoxicity elicited by zinc either as the pure salt or contained in the cycad flour preparations on cultured cerebellar granule cells is not mediated by cxcitatory amino acid receptor activation.

Two additional sets of experiments were undertaken to confirm our suspicion that zinc was responsible for the neurotoxicity of the flour extracts. These experiments were aimed at either removing zinc from the toxic samples, or blocking its neurotoxic actions. Because EDTA binds zinc with high affinity (Silen and Martell, 1971), we exposed both cultures to neurotoxic concentrations of zinc in the presence of EDTA. Under these conditions, EDTA completely abolished neurotoxicity. Similarly, EDTA blocked the neurotoxicity of the toxic flour extracts. We also pretreated toxic flour extracts with ammonium sulfide to precipitate zinc as its insoluble sulfide. When the supernatant from these samples was then added to cultured cerebellar granule cells, no toxicity was observed. Both these findings are consistent with the hypothesis that zinc is the neurotoxin.

In conclusion, studies employing two separate neuronal culture systems fail to provide evidence that there is a neurotoxic component in raw Cycas seeds. Cycad extracts are not significantly more toxic than extracts prepared from wheat flour, and there is no correlation between BMAA content and sample toxicity. In all instances, BMAA levels at toxic concentrations were orders of magnitude lower than those predetermined as neu- 
rotoxic. Our studies to date suggest that BMAA is an improbable cause of the ALS-PD of Guam.

Surprisingly, our studies of processed cycad flour have indicaled that the washing process has the potential to introduce toxic constituents into the flour samples. Although the traditional method of processing flour samples by the Chamorros indigenes of Guam reduces the amount of most water-soluble components, this process apparently introduces toxic amounts of zinc into some flour samples. To determine if zinc could be introduced this way, we mimicked the washing procedure in the laboratory using a zinc-lined (i.e., galvanized) container. After $7 \mathrm{~d}$ of soaking, the zinc content in the seeds rose to $1.2 \mathrm{mg} / \mathrm{gm}$. This is approximately one-third of that found in the most toxic sample; presumably longer soaking would result in increased zinc uptake.

Although we have no direct data to support the claim, it is interesting to speculate whether zinc may play an etiologic role in the ALS-PD of Guam. In vivo studies have been remarkably unsuccessful in identifying a link between crude cycads and ALS-PD. At least two groups have undertaken long-term feeding studies employing unprocessed cycad meal (i.e., C. circinalis) and have been unable to identify any behavioral changes or relevant neuropathology (Sieber et al., 1980; Garruto et al., 1989). The limited experimental data in support of an association between cycads and ALS-PD come from Dastur (1964), where suggestive neuropathology was found in one animal of three fed processed cycad flour, and the work of Spencer et al. (1987a) employing supradietary levels of BMAA.

Our results suggest that because traditional cycad flour preparation may introduce high levels of zinc, the neurologic consequences of long-term zinc ingestion deserve further study. Consumption of about $250 \mathrm{gm} / \mathrm{d}$ of zinc-containing flour could deliver about $1 \mathrm{gm} / \mathrm{d}$ of zinc, that is, quantities 100 times higher than the daily requirement for humans. The mechanism of zinc toxicity in cultured neurons is unknown, and the consequences of long-term exposure to high levels of zinc are not well defined. Zinc ( $4 \mathrm{mg} / \mathrm{kg}$ ) causes lassitude, enteritis, and paresis of the hind limbs in dogs (Vallee, 1959). Zinc has been reported to disturb neurofilament assembly in vitro (Banerjee et al., 1982) and neurofilament aggregates in vitro (Kress et al., 1981), and is increased in affected areas in parkinsonian brains (Dexter et al., 1989). Zinc has also been demonstrated to influence the homeostasis of other divalent metal ions (Fox, 1989). These data suggest that zinc, along with the dietary imbalance in divalent cations, may impair neuronal function. Further epidemiologic and animal feeding studies regarding the consequences of longterm dietary zinc ingestion seem warranted and may clarify the role of zinc neurotoxicity.

\section{References}

Banerjee A, Roychowdhury S, Bhattacharya B (1982) Zinc-induced self-assembly of goat brain tubulin: some novel aspects. Biochem Biophys Res Commun 105:1503-1510.

Bcrger B, DiPorzio DU, Daguet MC, Gay M, Vigny $\Lambda$, Glowinski J, Prochiartz A (1982) Long-term development of mesencephalic dopaminergic neurons of mouse embryos in dissociated primary cultures: morphological and histochemical characteristics. Neuruscience 7:193-205

Borenfreund E, Babich H (1987) In vitro cytotoxicity of heavy metals, acrylamide, and organotin salts to neural cells and fibroblasts. Cell Biol Toxicol 3:63-73.

Choi DW, Yokoyama M, Koh J (1988) Zinc neurotoxicity in cortical cell culture. Neuroscience 24:67-79.
Dastur KD (1964) Cycad toxicity in monkeys: clinical, pathological, and biochemical aspects. Fed Proc 23:1368-1369.

Dexter DT, Wells FR, Lees AJ, Agid F, Agid Y, Jenner P, Marsden CD (1989) Increased nigral iron content and alterations in other metal ions occurring in brain in Parkinson's disease. J Neurochem 52:1830 1836.

Di Porzio U, Daguet M-C, Glowinski J, Prochiantz A (1980) Effect of striatal cells on in vitro maturation of mesencephalic dopaminergic neurones grown in serum-free conditions. Nature 288:370-373.

Duncan MW (1991) The role of the cycad neurotoxin BMAA in the ALS-PD of the western Pacific. In: Advances in neurology, Vol 56, Amyotrophic lateral sclerosis and other motor neuron diseases (Rowland LP, ed), pp 301-310. New York: Raven.

Duncan MW, Kopin IJ, Garruto RM, Lavine L, Markey SP (1988) 2-Amino-3-(methylamino)-propionic acid in cycad-derived foods is an unlikely cause of amyotrophic lateral sclerosis/parkinsonism [letter]. Lancet 2:631-632.

Duncan MW, Kopin IJ, Crowley JS, Jones SM, Markey SP (1989) Quantification of the putative neurotoxin 2-amino-3-(methylamino)propanoic acid (BMAA) in cycadales: analysis of the seeds of some members of the family Cycadaceae. J Anal Toxicol 13:169-175.

Duncan MW, Steele JC, Kopin IJ, Markey SP (1990) 2-Amino-3(methylamino)-propanoic acid (BMAA) in cycad flour: an unlikely cause of amyotrophic lateral sclerosis and parkinsonism-dementia of Guam. Neurology 40:767-772.

Fox MRS (1989) Zinc excess. In: Zinc in human biology (Mills CF, ed), pp 365-369. Berlin: Springer.

Gallo V, Suiergiu R, Giovanni C, Levi G (1987) Glutamate receptor subtypes in cultured cerebellar neurons: modulation of glutamate and gamma-aminobutyric acid release. J Neurochem 49:1801-1809.

Garruto RM, Yase Y (1974) Neurodegenerative disorders in the Pacific. Trends Neurosci 9:368-374.

Garruto RM, Shankar SK, Yanagihara R, Salazar AM, Amyx HL, Gajdusek DC (1989) Low-calcium, high-aluminum diet-induced motor neuron pathology in cynomologus monkeys. Acta Neuropathol (Berl) 78:210-219.

Hirano A, Kurland LT, Krooth RS, Lessell S (196la) Parkinsonismdementia complex, an endemic disease on the island of Guam. I. Clinical features. Brain 84:642-661.

Hirano A, Malamud N, Kurland LT (1961b) Parkinsonism-dementia complex, an endemic disease on the island of Guam. II. Pathological features. Brain 84:662-679.

Koh J-y, Choi DW (1988) Zinc alters excitatory amino acid neurotoxicity on cortical neurons. J Neurosci 8:2164-217I.

Kress Y, Gaskin F, Brosnan CF, Levine S (1981) Effects of zinc on the cytoskeletal proteins in the central nervous system of the rat. Brain Res 220:139-149.

Kurland LT (1988) Amyotrophic lateral sclerosis and Parkinson's disease complex on Guam linked to an environmental neurotoxin. Trends Neurosci 11:51-54.

Lipsky R, Silverman SJ (1987) Effects of mycophenolic acid on detection of glial filaments in human and rat astrocytoma cultures. Cancer Res 47:4900-4904.

Marini AM, Schwartz JP, Kopin IJ (1989) The neurotoxicity of 1 -methyl-4-phenylpyridinium in cultured cerebellar granule cells. J Neurosci 9:3665-3672.

Novelli A, Reilly JA, Lysko PG, Henneberry RC (1988) Glutamate becomes neurotoxic via the $N$-methyl-D-asparate receptor when intracellular energy levels are reduced. Brain Res 451:205-212.

Nunn PB, Seelig M, Zagoren JC, Spencer PS (1987) Stereospecific acute neuronotoxicity of 'uncommon' plant amino acids linked to human motor-system diseases. Brain Res 410:375-379.

Ross SM, Seelig M, Spencer PS (1987) Specific antagonism of excitotoxic action of 'uncommon' amino acids assayed in organotypic mouse cortical cultures. Brain Res 425:120-127.

Sieber SM, Correa P, Dalgard DW, McIntire KR, Adamson RH (1980) Carcinogenicity and hepatotoxicity of cycasin and its aglycone methylazoxymethanol acetate in nonhuman primates. J Natl Cancer Inst 65:177-189.

Silen L, Martell AE (1971) Stability constants of metal-ion complexes. Supplement no 1, special publication no 25, p 623. London: The Chemical Society.

Spencer PS, Nunn PB, Hugon J, Ludolph A, Roy DN (1986) Motorneurone disease on Guam: possible role of a food neurotoxin [letter]. Lancet 1:965. 
Spencer PS, Nunn PB, Hugon J, Ludolph AC, Ross SM, Roy DN, Robertson RC (1987a) Guam amyotrophic lateral sclerosis-parkinsonism-dementia linked to a plant excitant neurotoxin. Science 237: 517-522.

Spencer PS, Palmer VS, Herman A, Asmedi A (1987b) Cycad use and motor neurone disease in Irian Jaya [letter]. Lancet 2:1273-1274.

Spencer PS, Ohta M, Palmer VS (1987c) Cycad use and motor neurone disease in Kii peninsula of Japan [letter]. Lancet 2:1462-1463.

Vallee BL (1959) Biochemistry, physiology and pathology of zinc. Physiol Rev 39:443-490.
Weiss JH, Choi DW (1988) Beta- $N$-methylamino-L-alanine neurotoxicity: requirement for bicarbonate as a cofactor. Science 241:973975

Weiss JH, Koh J-y, Choi DW (1989) Neurotoxicity of beta- $N$-methylamino-L-alanine (BMAA) and beta- $N$-oxalylamino-L-alanine (BOAA) on cultured cortical neurons. Brain Res 497:64-71.

Whiting MG (1963) Toxicity of cycads. Econ Bot 17:270-302.

Yamamoto T, Hirano A (1985) Nucleus raphe dorsalis in parkinsonism-dementia complex of Guam. Acta Neuropathol (Berl) 67:296299. 